Research papers

\title{
Local variation in the distribution of benthic megafauna species associated with cold-water coral reefs on the Norwegian margin
}

\author{
Autun Purser ${ }^{\mathrm{a}, *}$, Covadonga Orejas ${ }^{\mathrm{b}, \mathrm{c}}$, Andrea Gori ${ }^{\mathrm{c}}$, Ruiju Tong ${ }^{\mathrm{a}}$, \\ Vikram Unnithan $^{a}$, Laurenz Thomsen ${ }^{\text {a }}$ \\ a Jacobs University, Campus Ring 1, 28759 Bremen, Germany \\ ${ }^{\mathrm{b}}$ Instituto Español de Oceanografía (IEO), Centro Oceanográfico de Baleares, Moll de Ponent s/n, 07015 Palma de Mallorca, Illes Balears, Spain \\ ' Institut de Ciències del Mar (CSIC), Pg Maritim de la Barceloneta 37-49, 08003 Barcelona, Spain
}

\section{A R T I C L E I N F O}

\section{Article history:}

Received 14 May 2012

Received in revised form

21 December 2012

Accepted 31 December 2012

Available online 9 January 2013

\section{Keywords:}

Cold-water corals

Lophelia pertusa

Norway

Species distribution

\begin{abstract}
A B S T R A C T
The spatial variability in the mix of species making up Cold-water coral reef communities is not well known. In this study abundances of a selection of megafauna (Lophelia pertusa, Madrepora oculata, Paragorgia arborea, Primnoa resedaeformis, Mycale lingua, Geodia baretti, Acesta excavata and fish) were quantified throughout 9 manned submersible video transects from 3 reef complexes (Røst Reef, Sotbakken Reef and Traena Reef) on the Norwegian margin. Substrate type (coral structure, rubble, exposed hardground or soft sediment) was also recorded. Variations in the densities of these fauna (with respect to both reef complex and substrate type) were investigated, with spatial covariance between species assessed.

For the majority of fauna investigated, densities varied by both reef and substrate. Spatial covariance indicated that some species may be utilising similar habitat niches, but that minor environmental differences may favour colonisation by one or other at a particular reef. Fish densities were generally higher in regions with biogenic substrate (coral structure and coral rubble substrates) than in areas of soft or hardground substrate. Further, fish were more abundant at the northerly Sotbakken Reef at time of study than elsewhere. Community structure varied by reef, and therefore management plans aimed at maintaining the biodiversity of reef ecosystems on the Norwegian margin should take this lack of homogeneity into account.
\end{abstract}

(c) 2013 Elsevier Ltd. All rights reserved.

\section{Introduction}

Cold-water coral (CWC) reefs are recognised as biodiverse ecosystems throughout the oceans of the world (e.g., Roberts et al., 2006; Duineveld et al., 2007; Henry and Roberts, 2007; Reveillaud et al., 2008; Clark et al., 2010; Henry et al., 2010; Lessard-Pilon et al., 2010; D'Onghia et al., 2010; Mastrototaro et al., 2010). In European seas, these reefs are often located at depths associated with the edge of the continental shelf or deeper, commonly in regions with a hard substrate and high volumes of particulate organic matter regularly delivered to the benthic community. Elevated flow velocities close to the seabed, such as may be found at sills (Lavaleye et al., 2009; Rüggeberg et al., 2011; Wagner et al., 2011), seamounts or mound structures (De Mol et al., 2002; Kenyon et al., 2003; Duineveld et al., 2004; Dorschel et al., 2005; White, 2007; Frank et al., 2009; Rowden et al., 2010; Tracey et al., 2011), within canyons (Taviani et al., 2005; Orejas et al., 2009;

\footnotetext{
* Corresponding author. Tel.: +49421 2005865.

E-mail addresses: a.purser@jacobs-university.de, autunpurser@gmail.com (A. Purser).
}

Huvenne et al., 2011) or the edge of the continental shelf (Freiwald et al., 2002; Fosså et al., 2005; Wheeler et al., 2007) increase the suspended food flux locally, and may supply a suitable quantity for coral reef development (Duineveld et al., 2004; Davies et al., 2008; Wagner et al., 2011). Periodic downwellings from surface waters of fresh, labile material is an alternative primary food supply mechanism at some reefs (Davies et al., 2009, Duineveld et al., 2012).

Lophelia pertusa (Linnaeus, 1758) is the most common reef building scleractinian coral within the majority of European reef ecosystems (Roberts et al. 2009). With growth, coral polyps secrete an aragonite skeletal cup of $\sim 1 \mathrm{~cm}$ diameter, either directly onto the underlying substrate, on top of the dead skeletal remains of previous generations or as a bud from a living parent polyp. Despite a moderate longitudinal growth rate $\left(\sim 1 \mathrm{~cm} \mathrm{yr}^{-1}\right.$ appears to be a roughly average across European reefs (Mikkelsen et al., 1982; Rogers, 1999; Orejas et al., 2008, 2011; Roberts et al., 2009)), sizable reef frameworks can develop. Geological investigations have indicated that the development of the majority of current North European extant reefs likely commenced shortly after the retreat of ice at the end of the last ice age, $\sim 10,000$ years b. p. (Freiwald et al., 1999). From this date, reef complexes on the Norwegian margin have grown to form structures of varying size, 
from those consisting of collections of small coral thickets a few meters in diameter, to large structures many $\mathrm{km}$ in length and with heights above the substrate measured in tens of metres (Freiwald et al., 2002). These complex structures greatly increase habitat heterogeneity on the seabed (Reed et al., 1982; Henry and Roberts, 2007; Cordes et al., 2008; Roberts et al., 2009; BuhlMortensen et al., 2010). The aragonite skeleton laid down by scleractinian growth provides a hard substrate suitable for settlement by a variety of sessile organisms (Mortensen et al., 1995; Henry, 2001; López Correa et al., 2005; Metaxas and Davis, 2005; Roberts et al., 2006; Orejas et al., 2008; Purser et al., 2009). This skeletal structure also interacts with and impacts on local hydrodynamic flow (White, 2007) providing refuges for fish (Husebø et al., 2002; Auster, 2005; Costello et al., 2005; Edinger et al., 2007; Clark and Tittensor, 2010; Söffker et al., 2011; Baker et al., 2012) and other mobile invertebrate fauna (Reed et al., 1982; Henry and Roberts, 2007; O'Hara et al., 2008; Clark and Rowden, 2009; Lessard-Pilon et al., 2010; Buhl-Mortensen et al., 2010).

The extensive acoustic mapping of the continental margins and subsequent Remote Operated Vehicle (ROV), submersible or dropcam investigations carried out in the last decade has increased our knowledge on the distribution of CWC ecosystems on the European margins (Fosså et al., 2005; Davies et al., 2008; Dolan et al., 2008; Guinan et al., 2009; Orejas et al., 2009; Roberts et al., 2009; Schmiing et al. 2009; Fosså and Skjoldal, 2010; Vertino et al., 2010; Huvenne et al., 2011; Tong et al., 2012). Surveys of fauna within these ecosystems have however varied in overall aim, approach and methodology. Grab sampling and trawling have confirmed the presence of a high number of species at many reefs (Mortensen et al., 1995; Rogers, 1999; Roberts et al., 2006; Henry and Roberts, 2007; Cordes et al., 2008). Video transect data analysis has shown that at the majority of reefs distinct habitat zones are present, differentiated by substrate type (Jonsson et al., 2004; BuhlMortensen et al., 2010, Tong et al. 2012). These zones can be summarised as: (1) regions of high density, live scleractinian growth (the 'live reef zone'), (2) dead skeletal regions (the 'dead coral zone') and (3) a surrounding area made up of many broken coral fragments and occasional patches of living polyps (the 'rubble zone') (BuhlMortensen et al., 2010). The percentage of reef ecosystem made up of each of these habitat types differs between reefs, likely in response to differences in hydrodynamic regime, food supply or substrate availability (Kenyon et al., 2003; Wheeler et al., 2007; Wagner et al., 2011). Anthropogenic impact has also had an influence on shaping the physical form of many European reefs (Fosså and Skjoldal, 2010).

To date few studies have investigated how densities of species associated with CWC reefs may vary across and between reef habitat zones at individual reefs, or between different reef complexes. Where published, species occurrence data often reports abundances from reefs as a whole (Jensen and Frederiksen, 1992; Henry and Roberts, 2007), with a lesser number of studies attempting to assess beta diversity variation across individual reefs, reef complexes or the surrounding ecosystems (Jonsson et al., 2004; Raes and Vanreusel, 2006; Henry and Roberts, 2007; Rossi et al., 2008; Henry et al., 2010). The role of terrain morphology in influencing gorgonian coral distributions across several reefs was recently investigated on the Norwegian margin (Tong et al., 2012). In Orejas et al. (2009) small scale spatial distribution patterns of a selection of CWC species within a Western Mediterranean canyon system were investigated by using spatial pattern analyses developed for use in terrestrial environments. In this study we used a similar methodology to investigate small scale spatial distribution of a selection of benthic megafaunal species associated with CWC reefs on the Norwegian margin. This area of the continental shelf is rich in CWC ecosystems, as well as being an area of significant human utilisation, with an active fishery and offshore oil and gas exploration and production ongoing (Fosså and Skjoldal, 2010).

The main aims of our investigation were: (1) to try and determine whether or not the distribution of associated benthic megafauna species varied by reef, substrate type, or with variation in the densities of other megafauna species and (2) to try and determine whether or not the occurrence and the abundance of fish varied with reef, substrate type, or the densities of the investigated seafloor species.

\section{Materials and methods}

\subsection{Survey sites}

Three Norwegian reef complexes, Røst Reef, Traena Reef and Sotbakken Reef (Table 1, Fig. 1), were investigated with the 'RV Polarstern' during cruise ARKXXII/1a, June 2007 (Klages and Thiede, 2011). All three reefs are exposed primarily to the Norwegian North Atlantic Current, flowing SW-NE parallel to the Norwegian coast (Dullo et al., 2008).

The Røst Reef complex is one of the most spatially extensive in Norwegian waters (Thorsnes et al., 2004; Dullo et al., 2008; Wehrmann et al., 2009), and has been protected from bottom trawling since 2003 (Fosså et al., 2005; Hall-Spencer et al., 2008). The complex is formed from a number of healthy coral banks located on the crests of ridges running parallel to the edge of the continental margin, formed by the Traenadjupet landslide during the Cenozoic (Damuth, 1978). Between each coral bank there are depressed regions of coral rubble and less vigorously growing coral thickets (Wehrmann et al., 2009).

The Traena Reef complex contains a number of elongated coral structures, each up to $\sim 150 \mathrm{~m}$ in length, growing into the prevailing current direction on the continental shelf. Previous investigation has shown these coral structures to consist of a live coral 'head' or upstream section, downstream of which is a more degraded region of coral structure where sparse living coral growth can be found, trailed and surrounded by an area of coral rubble (Fosså et al., 2005; Buhl-Mortensen et al., 2010; Tong et al., 2012).

The Sotbakken Reef has not been visited often by the research community. Mapping and preliminary oceanographic data from the reef are presented in the G.O. Sars cruise 2005108 and Polarstern FS70 cruise reports (Fosså, 2005; Klages and Thiede, 2011). A recent paper (Tong et al., 2012) relates gorgonian distribution at the reef to physical terrain variables such as seabed slope and orientation, though no other fauna are investigated. At $70^{\circ} 45^{\prime} \mathrm{N}$ the reef is close to the northerly limit of (documented) L. pertusa occurrence (Fosså et al., 2000).

\subsection{Video sampling}

The manned submersible JAGO (IFM-Geomar) was used to collect high definition (HD) quality video data with imbedded universal time code (UTC) throughout dives at each reef (Table 1, Fig. 1). The submarine dives were planned to cross cut reef structures, either by travelling from the deepest depths of reef structure occurrence to the shallowest (Røst Reef and Sotbakken Reef) or by passing along the length of the cigar-like reef structures (Traena Reef). Submarine positioning was maintained throughout the dives via a LinkQuest TrackLink 1500 HA USBL positioning system. A pair of parallel laser pointers (positioned $50 \mathrm{~cm}$ apart) were used to provide image scale. The camera provided a view of roughly $10 \mathrm{~m}^{2}$ of seabed, given a submarine altitude of $\sim 1 \mathrm{~m}$ above seafloor. The videos were replayed using the Adobe CS4 Premiere Pro software package and the passage of 
Table 1

Sampling location, dive designation, date, time, position (start and end), depth, temperature and total usable length of each transect analysed.

\begin{tabular}{|c|c|c|c|c|c|c|c|c|}
\hline \multirow[t]{2}{*}{ Transect } & \multirow{2}{*}{$\begin{array}{l}\text { JAGO Dive } \\
\text { code }\end{array}$} & \multirow[t]{2}{*}{ Date } & \multirow{2}{*}{$\begin{array}{l}\text { Start time } \\
\text { (GMT) }\end{array}$} & \multicolumn{2}{|l|}{ Transect co-ordinates } & \multirow{2}{*}{$\begin{array}{l}\text { Depth range } \\
(\mathrm{m})\end{array}$} & \multirow{2}{*}{$\begin{array}{l}\text { Average temp } \\
\left({ }^{\circ} \mathrm{C}\right)\end{array}$} & \multirow{2}{*}{$\begin{array}{l}\text { Usable footage } \\
(\mathrm{m})\end{array}$} \\
\hline & & & & From & To & & & \\
\hline Rost 1 & $9916 / 14-4$ & $9 / 6 / 2007$ & $11: 36$ & $67^{\circ} 29.93 \mathrm{~N}, 09^{\circ} 24.41 \mathrm{E}$ & $67^{\circ} 29.99 \mathrm{~N}, 09^{\circ} 24.34 \mathrm{E}$ & $282-291$ & 7.4 & 331 \\
\hline Rost 2 & 993 8/16-1 & $10 / 6 / 2007$ & 09:19 & $67^{\circ} 30.86 \mathrm{~N}, 09^{\circ} 26.57 \mathrm{E}$ & $67^{\circ} 30.70 \mathrm{~N}, 09^{\circ} 26.48 \mathrm{E}$ & $306-353$ & 7.3 & 350 \\
\hline Rost 3 & 998 13/29-1 & $15 / 6 / 2007$ & 09:36 & $67^{\circ} 33.06 \mathrm{~N}, 09^{\circ} 32.73 \mathrm{E}$ & $67^{\circ} 33.02 \mathrm{~N}, 09^{\circ} 32.96 \mathrm{E}$ & $283-330$ & 7.3 & 340 \\
\hline Rost 4 & 999 14/31-1 & $15 / 6 / 2007$ & $17: 11$ & $67^{\circ} 31.34 \mathrm{~N}, 09^{\circ} 28.02 \mathrm{E}$ & $67^{\circ} 31.31 \mathrm{~N}, 09^{\circ} 28.23 \mathrm{E}$ & $358-388$ & 7.3 & 247 \\
\hline Sotbakken 1 & $100217 / 40-4$ & $18 / 6 / 2007$ & $12: 48$ & $70^{\circ} 45.30 \mathrm{~N}, 18^{\circ} 39.72 \mathrm{E}$ & $70^{\circ} 45.38 \mathrm{~N}, 18^{\circ} 39.95 \mathrm{E}$ & $247-269$ & 6.5 & 452 \\
\hline Sotbakken 2 & $100318 / 41-2$ & $19 / 6 / 2007$ & 09:26 & $70^{\circ} 45.14 \mathrm{~N}, 18^{\circ} 40.70 \mathrm{E}$ & $70^{\circ} 45.36 \mathrm{~N}, 18^{\circ} 39.76 \mathrm{E}$ & $246-280$ & 6.5 & 568 \\
\hline Sotbakken 3 & $100419 / 42-1$ & $19 / 6 / 2007$ & $17: 26$ & $70^{\circ} 45.79 \mathrm{~N}, 18^{\circ} 41.60 \mathrm{E}$ & $70^{\circ} 45.98 \mathrm{~N}, 18^{\circ} 41.53 \mathrm{E}$ & $256-284$ & 6.5 & 345 \\
\hline Traena 1 & 995 10/24-2 & $13 / 6 / 2007$ & $16: 55$ & $66^{\circ} 58.09 \mathrm{~N}, 11^{\circ} 08.49 \mathrm{E}$ & $66^{\circ} 58.13 \mathrm{~N}, 11^{\circ} 07.29 \mathrm{E}$ & 297-319 & 7.3 & 227 \\
\hline Traena 2 & $99611 / 26-1$ & $14 / 6 / 2007$ & $10: 08$ & $66^{\circ} 58.19 \mathrm{~N}, 11^{\circ} 07.20 \mathrm{E}$ & $66^{\circ} 58.18 \mathrm{~N}, 11^{\circ} 07.23 \mathrm{E}$ & $305-314$ & 7.3 & 368 \\
\hline TOTAL & & & & & & & & 3228 \\
\hline
\end{tabular}
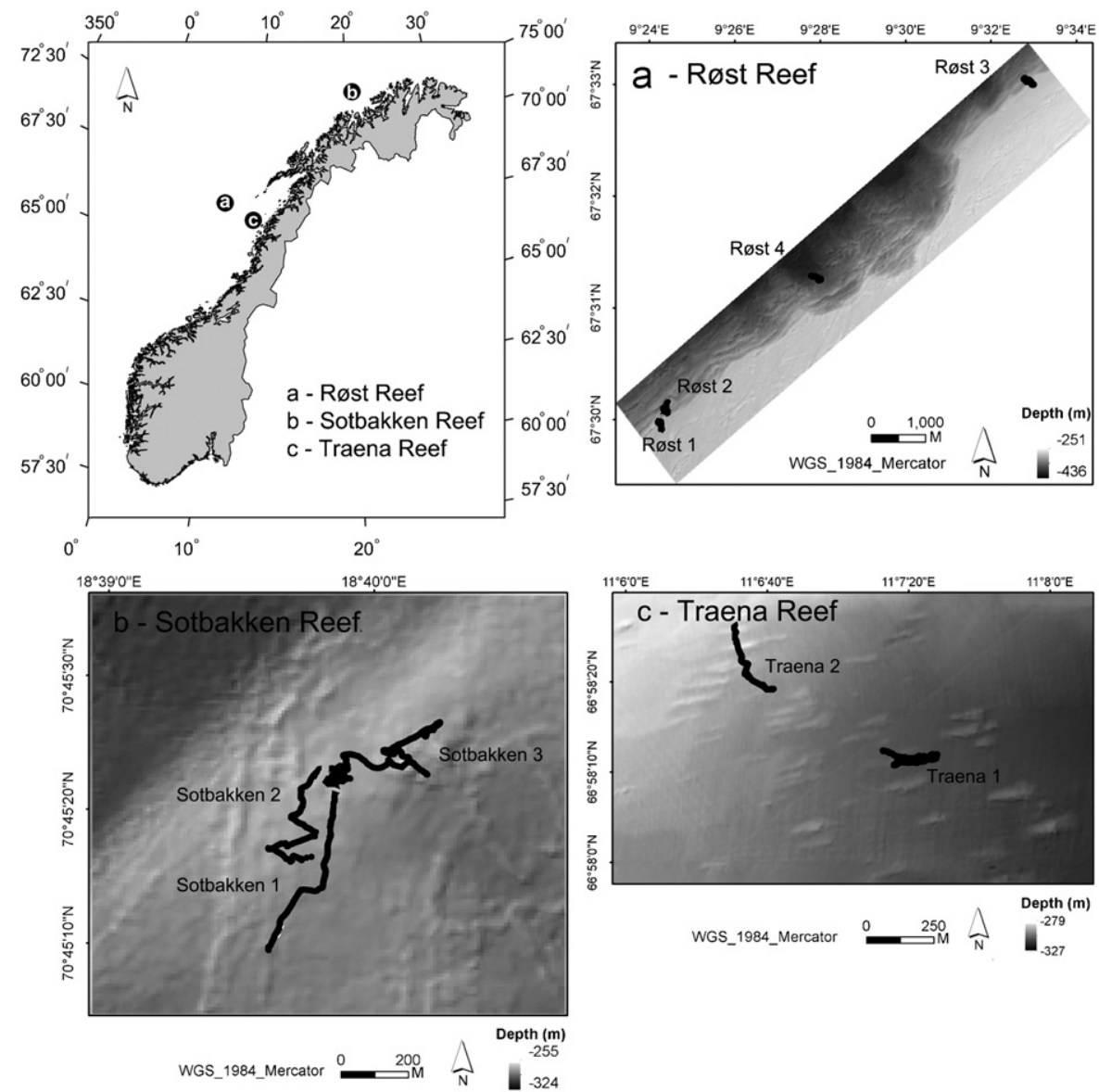

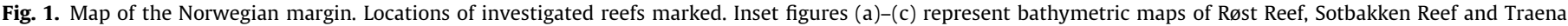
Reef, respectively, with dive tracks marked. Across each reef, the dive survey transects are clearly marked and numbered.

each substrate type or fauna individual (see Sections 2.3 and 2.4 ) through a $1.5 \mathrm{~m}$ wide swathe of seabed (this swathe formed from the horizontal line between laser points, plus comparable length continuations of this line to the left and right of the laser points) were recorded. The submarine position data collected by the LinkQuest system was then used in combination with the video time-codes to assign a linear distance from start of each transect for each of these recorded observations. The observations were then divided into $1 \times 1.5 \mathrm{~m}^{2}$ quadrats for the full length of each video transect; Quadrats were defined considering the transect distance travelled as determined from the LinkQuest position as the $1 \mathrm{~m}$ quadrat axis, the $1.5 \mathrm{~m}$ axis divided from the swathe between and to either side of the lazer points. The densities of each species of interest within each quadrat were computed. Wherever image quality was low due to excess turbidity/unsuitable viewing angle etc. a gap was recorded in the transect data.

\subsection{Substrate categories}

Substrate passing through the $1.5 \mathrm{~m}$ swathe throughout each dive transect was placed into one of four categories: (1) soft sediment (2) hardground compacted sediment (3) coral rubble (4) coral structure (comprising both living and dead coral framework) (Fig. 2). In situations where two substrate types were present within the $1.5 \mathrm{~m}$ swathe, the dominant ( $>50 \%$ ) coverage category was assigned. These substrate categories were selected 
to allow fauna density comparisons to be made between regions of biogenic substrate (coral structure and coral rubble categories) and those not originating from CWC reef development (hardground compacted sediment and soft sediment categories). Though further categories could possibly have been derived from the video data (such as 'coral wall', 'soft sediment with pebbles' etc.), we concluded that to do so would have made analysis more cumbersome and the areas of seafloor covered by each category more unequal. Further categories would have reduced the number of transect sections suitable for Morisita's index of patchiness analysis (see Section 2.5.1).

\subsection{Investigated species}

A selection of megafauna species were recorded throughout the video transects. Additionally, any sightings of fish, regardless of species, were recorded (hereafter, the investigated species and fish will be referred to as the 'fauna categories') (Fig. 3). Observations of lost fishing equipment or litter were also logged. The selection of species to be investigated was based primarily on ease of identification from the video data collected, with larger reef species preferentially selected. Samples of the sessile investigated species (fish were not sampled) were collected directly by the JAGO submersible during dive transects, to ground truth the video observations. Despite this groundtruthing, there may have been a degree of misidentification of the more difficult fauna from the video data, particularly of the two sponge species, Geodia baretti and Mycale lingua.

L. pertusa (Linnaeus, 1758), the most widespread and significant habitat building scleractinian coral in European waters (Wilson, 1979; Mortensen et al., 1995; Roberts et al., 2009), was recorded by live coral coverage \% throughout each transect. Five grades of coverage were used: $0 \%, 1-25 \%, 25-50 \%, 50-75 \%$ and
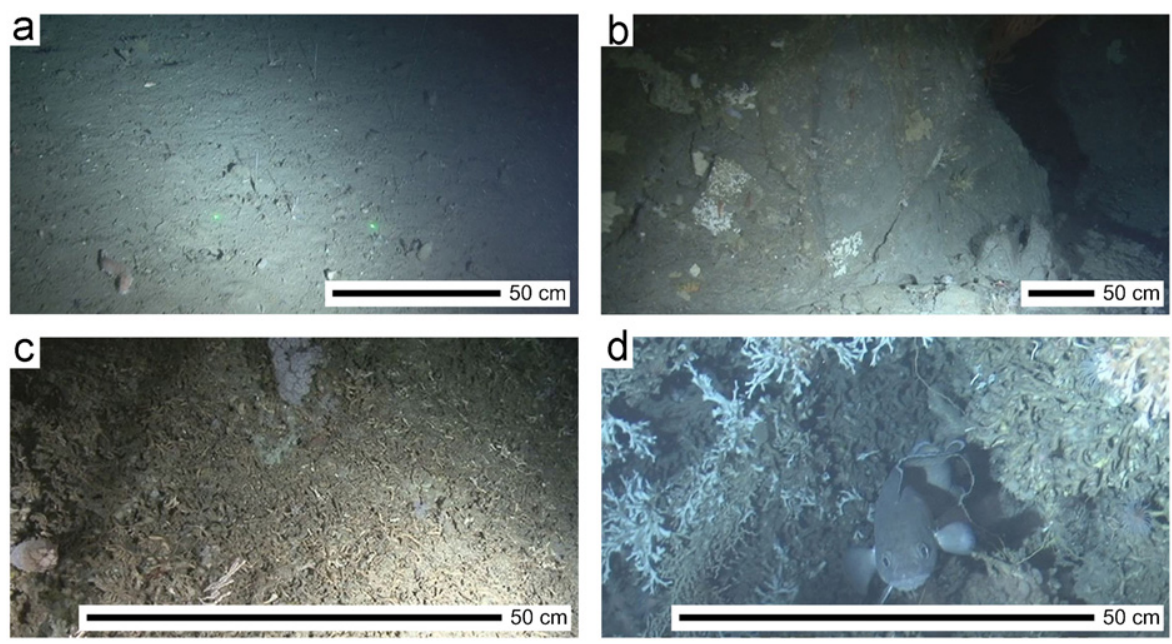

Fig. 2. Substrate categories used in this study. (a) Soft sediment. (b) Hardground. (c) Coral rubble. (d) Coral framework (with fish). Scale bar represent $50 \mathrm{~cm}$.
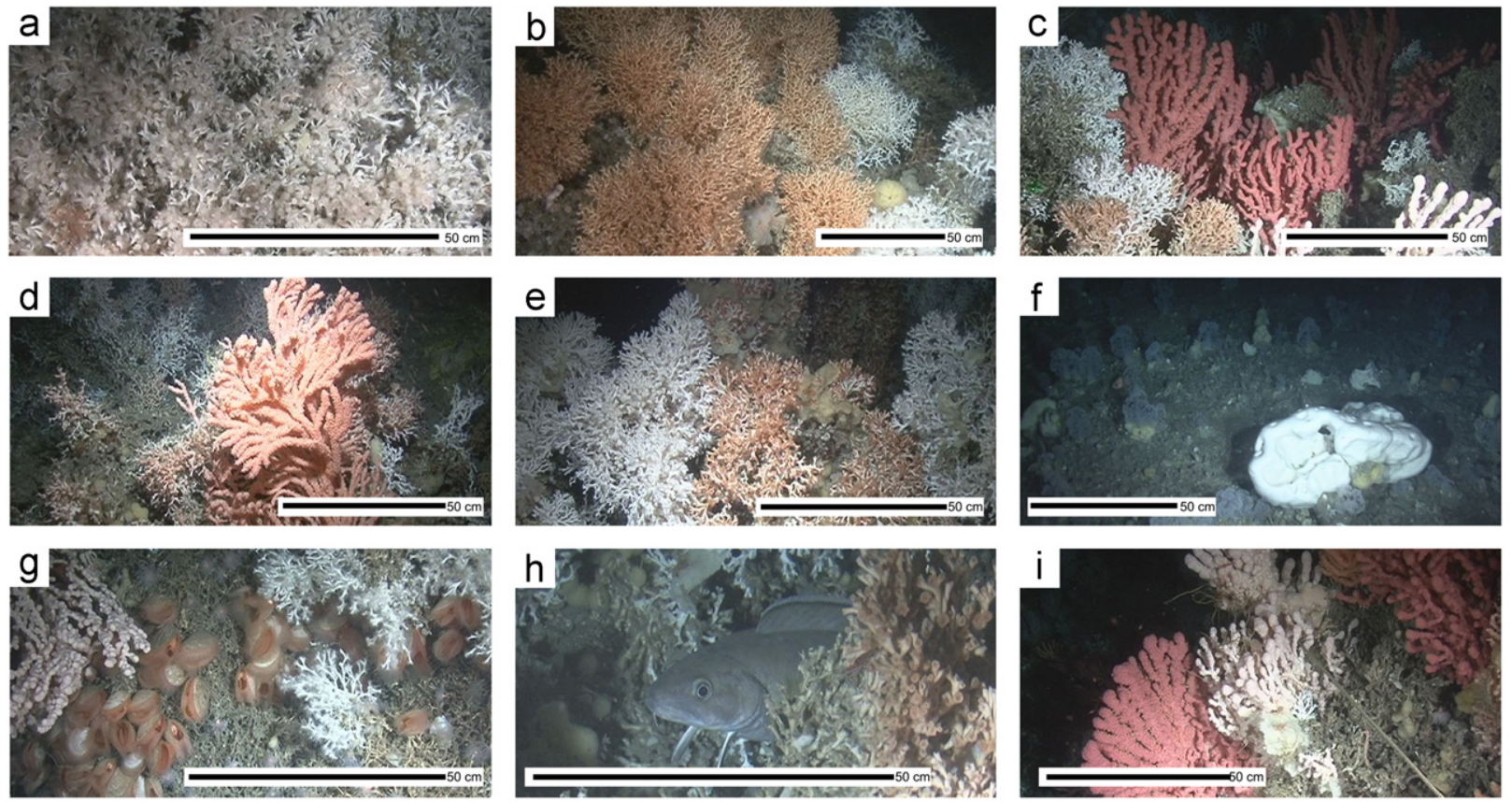

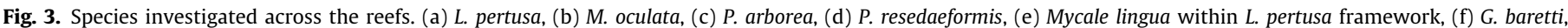
(g) A. excavata, (h) Fish with coral framework and (i) Rope trapped within coral framework and $P$. arborea colonies. Scale bar represent $50 \mathrm{~cm}$. 
75-100\%, with each $1 \mathrm{~m}$ section of transect being assigned one of these grades.

Madrepora oculata, Linnaeus, 1758, a scleractinian coral with a widely reported distribution on the Norwegian margin (Fosså et al., 2002; Freiwald and Wilson, 1998; Fosså et al., 2005; Reitner, 2005) and elsewhere (Orejas et al., 2009; Roberts et al., 2009; Vertino et al., 2010). The species forms a less expansive and less resilient framework structure than $L$. pertusa (Zibrowius, 1984). In this study this species was recorded by patch occurrence (patches $\mathrm{m}^{-2}$ ), as the observed patches were not extensive enough to warrant seabed \% coverage estimates, as recorded for $L$. pertusa.

Paragorgia arborea (Linnaeus, 1758) is one of the gorgonian corals most frequently found in CWC ecosystems, often positioned prominently on the top of ridges or boulders, with colonies curving into the prevailing current (Mortensen et al., 1995; Risk et al., 2002; Mortensen and Buhl-Mortensen, 2005). Colonies can measure several meters in height (Mortensen and Buhl-Mortensen, 2005) providing habitat niches for a selection of invertebrates (BuhlMortensen and Mortensen, 2004) and fish (Krieger, 1993). Throughout each transect, $P$. arborea were recorded by colony occurrence $\left(\right.$ col. $\mathrm{m}^{-2}$ ). Colony size was logged as either $>50 \mathrm{~cm}$ or $<50 \mathrm{~cm}$ height, with the size estimation based on the fixed $50 \mathrm{~cm}$ laser spacing distance. The aim of gauging $P$. arborea colony size was to investigate whether or not any observed differences in the sizes of this prominent organism corresponded to differing levels of fishing activity (as indicated by the presence of lost fishing equipment or historical fishery records).

Primnoa resedaeformis (Gunnerus, 1763) is another gorgonian coral commonly found on the Norwegian margin (Mortensen et al., 1995). This species tends to form less sizable colonies than $P$. arborea (Watanabe et al., 2009), but with a greater number of branches and a higher polyp density on those branches (Mortensen and BuhlMortensen, 2005). P. resedaeformis colonies have often been reported in close proximity to $P$. arborea (Andrews et al., 2002). P. resedaeformis colonies also provide habitat niches for a host of invertebrates (Buhl-Mortensen and Mortensen, 2004; Metaxas and Davis, 2005), hydroids (Henry, 2001), and fish (Krieger and Wing, 2002). This species was recorded throughout each transect by colony occurrence (col. $\mathrm{m}^{-2}$ ).

M. lingua (Bowerbank, 1866) is one of the few sponge species which can successfully colonise areas of reef where the density of living L. pertusa is high (Armstrong et al., 2009; Purser et al., 2009). As a non-selective grazer of small ( $<10 \mu \mathrm{m}$ ) plankton (Pile et al., 1996) M. lingua may well benefit from the additional food flux associated with the increased flow velocities found above L. pertusa structure. The species was recorded throughout each transect by individual sponge occurrence (ind. $\mathrm{m}^{-2}$ ), though it is to be noted that differentiation of individuals can be difficult in areas of high sponge density.

G. baretti Bowerbank, 1858 is a common sponge species found across the Norwegian margin, often in abundance in the general vicinity of CWC ecosystems (Klitgaard and Tendal, 2004). Usually grey in colour, the sponge can form large, distinct barrel like forms with growth, providing habitat niches for other species. The sponge has been of interest to the pharmaceutical industry since the 1980 s, potentially rendering its distribution to be of commercial significance (Lidgren and Bohlin, 1988; Sjögren et al., 2004). The species was recorded throughout each transect by individual occurrence (ind. $\mathrm{m}^{-2}$ ).

Acesta excavata (Fabricius, 1779) is the largest ( $>10 \mathrm{~cm}$ shell diameter) of the bivalves commonly found in CWC habitats on the Norwegian margin (Hovland, 2005; López Correa et al., 2005), in fjord settings (Gilmour, 1990), or on rock outcrops (Gagnon and Haedrich, 2003). Although widely reported, variation in population density between and across reefs has not been described in detail to date. This bivalve is often situated on the edges of vertical structures within reefs, or on the edges of reef crests within live $L$. pertusa structure. The species was recorded as individuals occurrence (ind. $\mathrm{m}^{-2}$ ) throughout each transect.

Fish were not recorded to species level, with all fish observations summed together into one fauna category for analysis. To quantify fish distribution across the reefs a different logging strategy was used than with the sessile fauna. Each fish coming into the field of view of the camera was recorded on first observation, regardless of whether it actually passed within the $1.5 \mathrm{~m}$ transect swathe. The field of view of the JAGO submarine was assumed to cover $10 \mathrm{~m}^{2}$ of seabed (see 2.2), and fish densities were based on this area estimation (ind. $\mathrm{m}^{-2}$ ). Fish densities have historically been assessed from survey trawls conducted over large areas (Gordon, 2001) whereas in this study the aim was to assess distributions at a smaller spatial scale and to see if observations of fish densities correlated with particular substrates, reef, or densities of the investigated benthic species.

Anthropogenic material was recorded (items $\mathrm{m}^{-2}$ ) with all pieces of rubbish or lost fishing equipment observed in the dive transect videos passing through the $1.5 \mathrm{~m}$ transect swathe being logged.

\subsection{Statistics}

\subsubsection{Sessile species and fish density variation}

Mean densities of each fauna category observed on or above each of the substrate categories was determined for each transect. Morisita's index of patchiness (Morisita, 1959) was used to assess whether individuals or colonies of the investigated species tended to be distributed randomly along the dive transects, or were clustered in distribution. This index has been increasingly used in tropical reef environments for distribution analysis (Hattori and Kobayashi, 2009; Lazar et al., 2011) The index is the scaled probability that two individuals (or colonies for the colonial organisms) present on a survey transect will be present in the same transect quadrat. Scores below 1 indicate a random distribution, with scores above 1 indicating a progressively greater degree of clustering with score increase. Given the lack of homogeneity within the dive transects, only sections of transect data where substrate category was uniform for $>20 \mathrm{~m}$ was used in computing this index score. Following analysis of all dive data from a particular reef, the average Morisita's index score for each fauna category found on each substrate type was determined for each reef. The PASSaGE 2.0 software package (Rosenberg and Anderson, 2011) was used to compute the Morisita's index of patchiness scores.

\subsubsection{Spatial covariance between fauna categories}

From the observations of each fauna category logged from each dive transect video, density plots were produced for each transect with the PASSaGE 2.0 software package as in previous studies on Mediterranean CWC and gorgonian species (Orejas et al., 2009; Gori et al., 2011a, 2011b). Spatial covariance's between $L$. pertusa coverage and densities of the other fauna categories, as well as for each paired combination of the other fauna categories across each transect were analyzed with a ThreeTerm Local Quadrat Covariance (3TLQC) analysis, using the PASSaGE 2.0 software package. In the 3 TLQC the variance as a function of block size for fauna category A (Var A), fauna category $B$ (Var B), and their combined number (Var $A+B)(C o v=\operatorname{Var}$ $A+B-$ Var A-Var B) is examined (Dale, 1999). To test the null hypothesis of an independent distribution of one fauna category with respect to the other along each transect, randomized transects were generated for comparison by randomly permuting the "labels" (fauna category A or B) of all the observed colonies/ organisms along each transect. For statistical significance 
(95\% confidence interval) the values at the limit of $2.5 \%$ tails of 999 of these randomizations was used. In the produced plots of covariance as a function of block size, positions of a significantly positive deviated sample statistic from the bounds of the confidence interval (peaks) indicates the scale of any positive association (attraction) between fauna categories, whereas significant negative deviations (valleys) indicate the scale of any negative association (repulsion) (Dale, 1999).

\subsubsection{Paragorgia arborea size variation}

One-way ANOVA tests were carried out to see whether there was a significant difference in $P$. arborea colony size between reef sites. All data was tested against a significance level of 0.05 . Post-hoc testing to determine between which reef and significant differences were logged was carried out using a LSD test. Statistical analyses were carried out using the SPSS v. 17.0 software package.

\section{Results}

\subsection{Species and fauna categories density variations}

\subsubsection{Lophelia pertusa}

Seabed coverage by live $L$. pertusa was higher across structure substrate on transects made at Røst Reef and Sotbakken Reef than at Traena Reef (Fig. 4). At Røst Reef and Sotbakken Reef, live coral percentage coverage varied from $0 \%$ to $>75 \%$ throughout each section of structure substrate surveyed (Figs. 5 and 6). At Traena Reef, areas of dense living coral ( $>75 \%$ coverage) were less than $\sim 10 \mathrm{~m}$ in transect length, located at one end of each area of structural substrate surveyed (Fig. 7), i.e., covering the upstream tips of the cigar-like reef structures (Fosså et al., 2005; BuhlMortensen et al., 2010).

\subsubsection{Madrepora oculata}

M. oculata was only observed at Røst Reef, and predominantly as patches $<50 \mathrm{~cm}$ diameter (data not shown). The highest density of patches observed was 0.061 patches $\mathrm{m}^{-2}$ on rubble during Røst Reef transect 2 (Table 2). Occasional the species was observed on hardground, soft sediment (attached to pebbles) during Røst Reef transects. Given the insufficiency of observations of this species, the data was not investigated statistically.

\subsubsection{Paragorgia arborea}

Highest densities of $P$. arborea were observed at Røst Reef (Table 2). Morisita's Index, (Table 3) indicated a tendency for a clustered distribution of $P$. arborea colonies across the various substrate categories.

\subsubsection{Primnoa resedaeformis}

$P$. resedaeformis was observed at all reefs surveyed in this study (Table 2). The highest densities recorded were at Røst Reef ( 0.35 col. $\mathrm{m}^{-2}$, structure substrate, Røst Transect 4$)$. Densities were higher in association with coral structure and hardground substrates than in areas of soft sediment. Morisita's index (Table 3) showed a generally clustered distribution of colonies throughout each substrate, with particularly tight clustering indicated by the index score $>10$ for colony densities recorded in association with hardground and structure at Røst Reef, and with coral structure at Sotbakken Reef.

\subsubsection{Mycale lingua}

Densities of $M$. lingua were similar at Røst Reef and Sotbakken Reef, with a lower density apparent at Traena Reef (Table 2). Densities were lower in regions of soft substrate than in areas of coral structure.
A clustered distribution of $M$. lingua was recorded on structure substrates at all reefs (Morisita's index $>9$ at all reefs, Table 3), particularly at Røst Reef (Morisita's index $=68.94, S D=218.26$ ). The high standard deviation in the Morisita's index scores indicates that in some locations clustering was very much greater than in others.

\subsubsection{Geodia baretti}

The highest density of $G$. baretti ( 0.37 individuals. $\mathrm{m}^{-2}$ ) was recorded on the hardground outcrops during Røst Reef transect 3 , 0.123 ind. $\mathrm{m}^{-2}(\mathrm{SD}=0.21)$, (Table 2$)$. Densities did not differ greatly by reef. The Morisita's index scores for all reefs indicated quite a random distribution (Table 3), although there was some significant clustering in some of the soft sediment areas of Sotbakken Reef (Morisita's index $=17.12, \mathrm{SD}=32.46$ ).

\subsubsection{Acesta excavata}

Much higher numbers of $A$. excavata were observed at Sotbakken Reef and Røst Reef that at Traena Reef (Table 2), with shells being observed exclusively in coral structure habitat category areas. A clustered distribution was indicated for this species (Morisita's index of $3.44(\mathrm{SD}=1.34)$ (Table 3 ) with the high number of shell observations (Table 2, Fig. 6) and low standard deviation across transects indicating a reasonably uniform pattern of clustering across the structure substrate.

\subsubsection{Fish}

The highest fish density recorded was associated with structure substrate during Sotbakken Reef transect $1\left(0.025\right.$ ind. $\left.\mathrm{m}^{-2}\right)$. A generally random distribution of fish across the various reefs and substrates was indicated (Table 3), although some clustering was indicated in association with rubble substrates at Sotbakken Reef (Morisita's index $=14.68, \mathrm{SD}=20.05$ ) and Traena Reef (Morisita's index $=31.33, \mathrm{SD}=38.85$ ).

\subsubsection{Anthropogenic material}

There were few clear signs of anthropogenic impact at any of the reefs visited. On 4 of the 9 transects occasional ropes were recorded on the seabed, with the most (5 occurrences) being recorded snagged within structural substrate during Traena Reef transect 1 (Table 2).

\subsection{Spatial covariance between species and fauna categories}

Given the range of species and fauna categories investigated in this study, the assessment of spatial covariance is complex, and presented in full in Table 4. Key results include:

1) Generally positive associations were indicated between $L$. pertusa and both $P$. arborea and $P$. resedaeformis across all the studied reefs.

2) L. pertusa and $M$. lingua were positively associated on a $\sim 10 \mathrm{~m}$ scale at Røst Reef, but not at the other surveyed reefs.

3) A negative covariance between $L$. pertusa and G. baretti.

4) A generally positive covariance between $P$. arborea and $P$. resedaeformis on a local $(\sim 5-20 \mathrm{~m})$ scale.

5 ) Both gorgonian species, $P$. arborea and $P$. resedaeformis, were positively associated with $A$. excavata bivalves on a scale of $\sim 10 \mathrm{~m}$.

6) Aside from a generally negative covariance with G. baretti, fish showed no clear spatial covariance trends with other investigated fauna.

\subsection{Paragorgia arborea size variation}

P. arborea colony size varied significantly with reef (ANOVA, $F=6.687, p<0.01$ ), with a Bonferroni multiple comparison indicating 


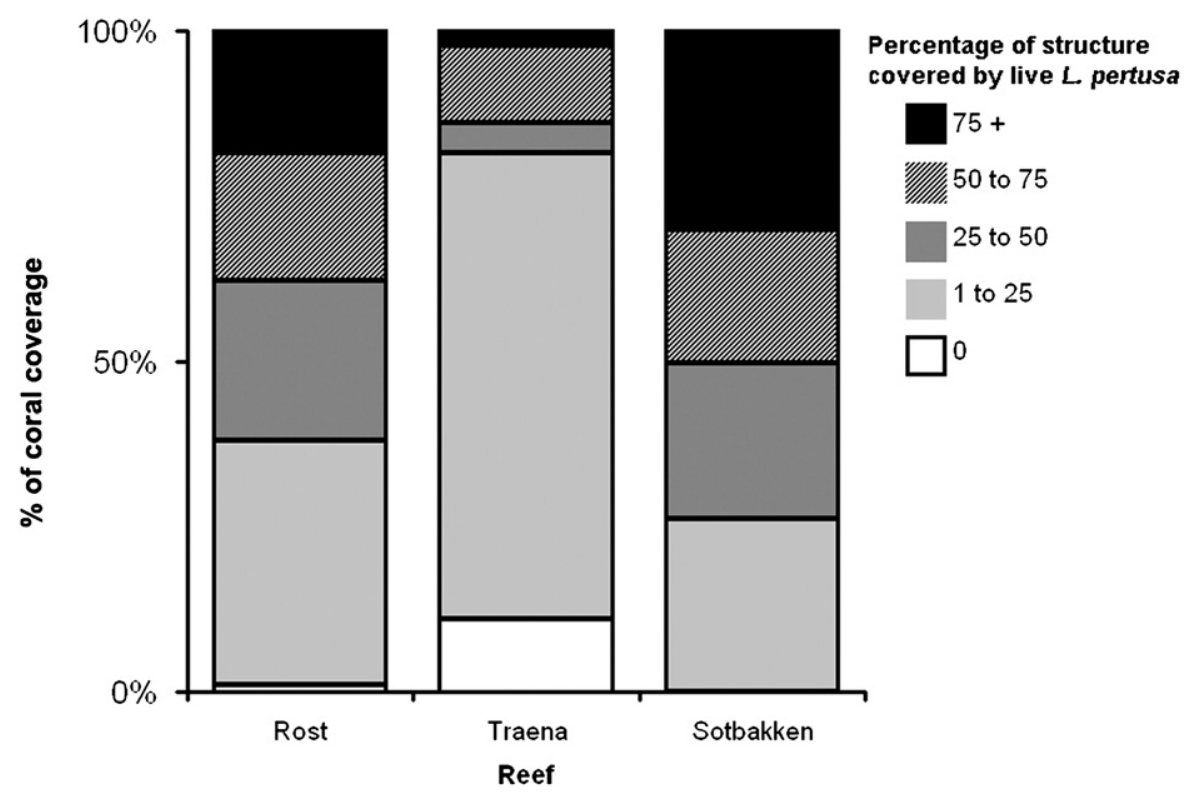

Fig. 4. L. pertusa live colony coverage of structure substrate at each reef. Coverage estimates are based on \% coverage of each transect quadrat covered by $L$. pertusa.

that this difference was significant between Røst Reef and Sotbakken Reef and Røst Reef and Traena Reef (Fig. 8). 80\% of colonies recorded at Røst Reef were $<50 \mathrm{~cm}$ in height, whereas at Sotbakken Reef and Traena Reef, $\sim 40 \%$ of colonies were $<50 \mathrm{~cm}$ in height.

\subsection{Anthropogenic material}

Clear evidence of anthropogenic impact on the reefs was limited to rare recordings of lost ropes, scattered across the surveyed reefs, lodged amongst coral structure (and occasionally rubble areas) of Røst Reef and Traena Reef (Table 2). The transects in this study were planned to cover as wide a range of reef habitats as possible, and did not focus on the edges of reef regions, with these regions commonly being those most often damaged by fishing activity ( $\mathrm{T}$. Lundälv, pers. comm.).

\section{Discussion}

The Røst Reef and Sotbakken Reef, both situated closer to the edge of the continental slope than the Traena Reef, may benefit from enhanced nutrient supplies resulting from slope related Ekman transport (Thiem et al., 2006), general cross-slope transport of organic rich particles which accumulated on the productive shelf seas (Thomsen, 1998) and tidal resuspension of material previously deposited on the slope (Kiriakoulakis et al., 2007). The flow regime in the bottom waters at Traena Reef has been reported to be unidirectional (Fosså et al., 2005; Klages and Thiede, 2011) whereas flow direction at the reefs on the edge of the continental slope is more variable in direction (Klages and Thiede, 2011). Sotbakken Reef was observed to be a well-developed reef (Tong et al., 2012), with spatially extensive regions of high density living $L$. pertusa.

\subsection{Fauna distribution}

The densities of the investigated species were generally higher at Røst Reef than at either Traena Reef or Sotbakken Reef.

\subsubsection{Paragorgia arborea}

The percentage of $P$. arborea colonies $>50 \mathrm{~cm}$ in height varied significantly with reef, with roughly twice the percentage of large colonies observed at Sotbakken Reef and Traena Reef than at Røst Reef. Occasional colonies at Sotbakken Reef appeared to be in excess of $2 \mathrm{~m}$ height (data not shown), approaching the reported species maximum in Norwegian waters (Broch, 1912 cited in Mortensen and Buhl-Mortensen, 2005). The temperature difference between the northerly and southerly developed reefs (Røst Reef and Sotbakken Reef) is unlikely the cause of the colony size difference, as (at time of study) the temperatures measured at both sites was comfortably within the range reported for the species (Leverette and Metaxas, 2005; Bryan and Metaxas, 2007). Differences in substrate can account for variation in maximum colony height (Mortensen and BuhlMortensen, 2005; Watanabe et al., 2009), although this is unlikely the cause here, given the comparable substrates available at each of these locations. P. arborea are often reported in areas with strong currents and less turbulent waters (Wainwright and Dillon, 1969; Warner, 1977), and possibly such favourable environmental conditions are more prevalent at Sotbakken Reef and Traena Reef than at Røst Reef. Tong et al. (2012) show that topographical features can have an influence on the distribution of the species, though in their study no attempt was made to determine whether the sizes of colonies also changed with particular terrain variables, such as slope, aspect or rugosity. A further possible explanation for this difference in colony heights could be that colonies at Røst Reef are younger than those at Sotbakken Reef. This could be the case if fishery activity in the vicinity of the Røst Reef has been higher during the last decades (Fosså and Skjoldal, 2010). Both trawl and long-line fishing are capable of readily dislodging $P$. arborea colonies from the seabed (Mortensen et al., 2005; Sherwood and Edinger, 2009). Although little direct evidence of fishing activity was observed during the survey dives in this study, reports of fishery activity in the literature and official reports for the Norwegian margin are summarised in Fosså et al. (2002). Therein they divide the Norwegian waters into 4 zones and tabulate the numbers of damaged and intact reefs reported from these zones by fishermen, industry and fishery surveys. The Røst Reef and Traena Reef are both located in their 'Zone 2', whereas Sotbakken Reef falls into 'Zone 1'. According to the combined data presented on known health status of reefs in each of these zones, $40 \%$ of those in Zone 1 were damaged by fishery activity, whereas $\sim 60 \%$ of those in 


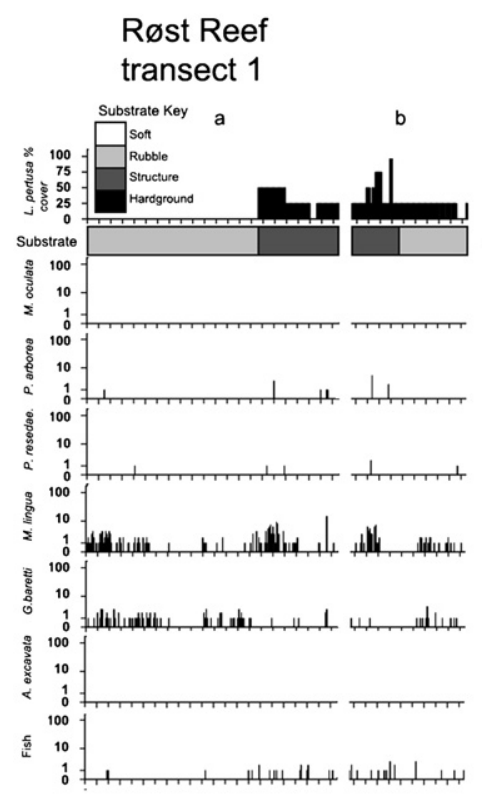

Røst Reef
transect 2

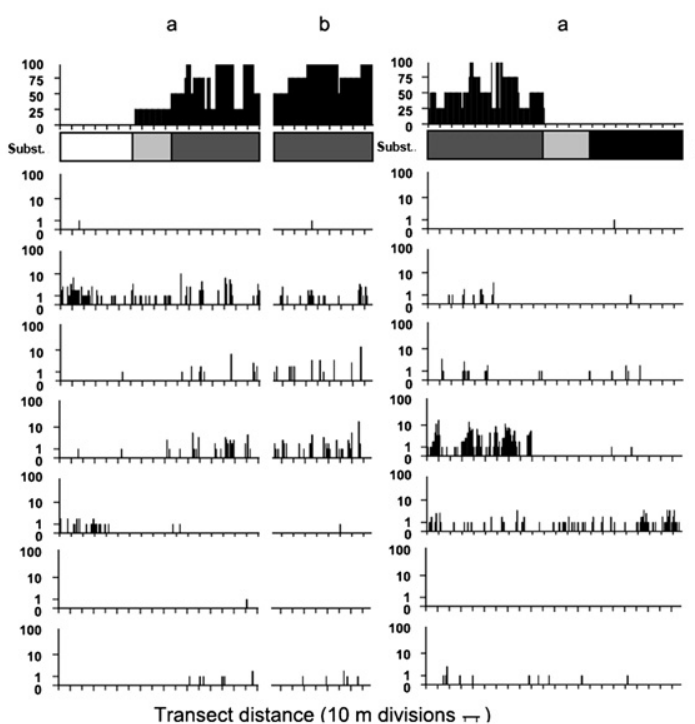

Røst Reef

transect 4

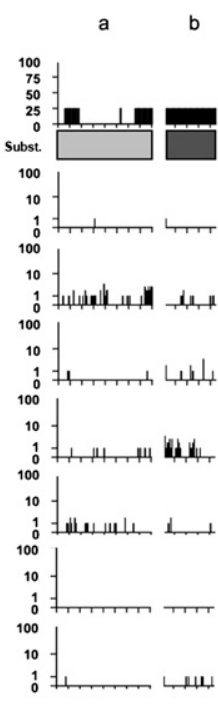

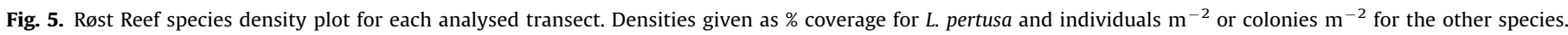
Letters represent the transect sections with usable video footage. Each division for the transect distance ( $x$ axis) correspond to $10 \mathrm{~m}$.

\section{Sotbakken Reef transect 1}

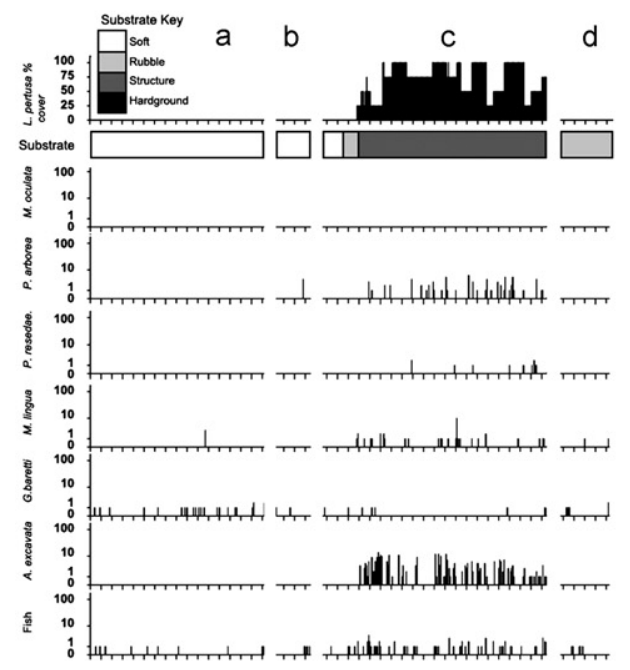

Sotbakken Reef transect 2

a

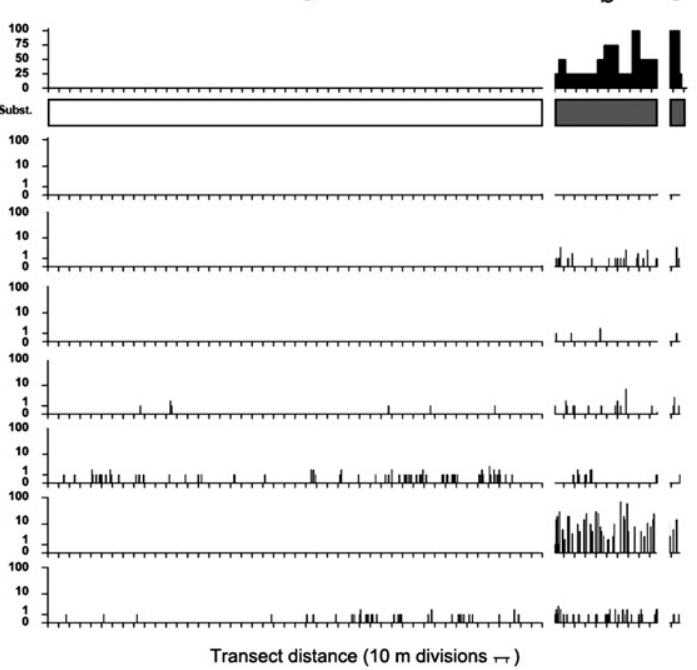

Sotbakken Reef transect 3

a

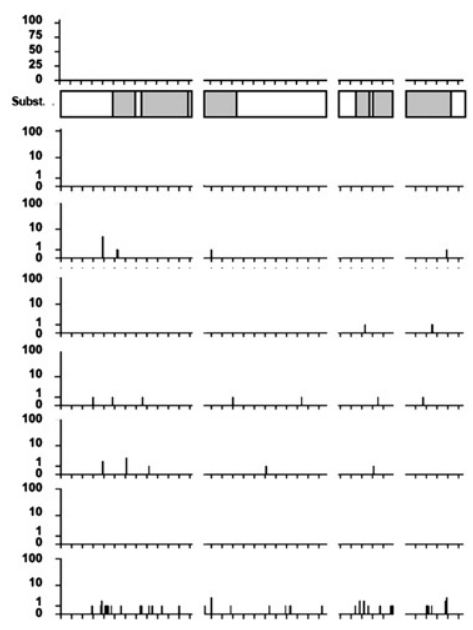

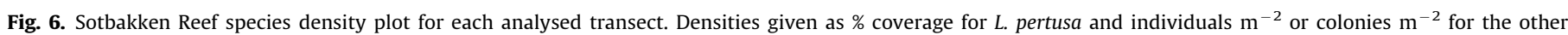
species. Letters represent the transect sections with usable video footage. Each division for the transect distance ( $x$ axis) correspond to 10 m.

Zone 2 were damaged. This is indicative of historically higher fishery activity in the vicinity of the southerly Røst Reef and Traena Reef than the more northerly Sotbakken Reef. The fish abundances recorded in the current study, though only a snapshot and not a representative or exhaustive data set, were higher at the Røst Reef than at the Traena Reef. Should this observation reflect the general condition, it is likely fishing effort prior to the fishery closure would have been higher in the vicinity of Røst Reef than Traena Reef. This greater activity could have resulted in a greater percentage removal of the more sizable colonies at Røst Reef than at Traena Reef. The positive covariance in $A$. excavata and $P$. arborea distributions (observed across all transects were both species were present) indicates that they may both utilise similar habitat or food sources.

\subsubsection{Primnoa resedaeformis}

The growth morphology and diet of $P$. resedaeformis differs from that of P. arborea (Wainwright and Dillon, 1969; Warner, 1977). Colonies were commonly observed within all transects to be draped over substrate, attached within grooves in reef structure or attached to the sides of structure blocks (Tong et al. 2012). Densities of $P$. resedaeformis were generally lower at Sotbakken Reef than at the more southerly reefs however. There are indications that under low temperature conditions, calcite growth is favoured over gorgonin in $P$. resedaeformis, which may have significance for the reduced colonisation success of this gorgonian within these slightly colder waters when compared with the slightly warmer waters found at Traena Reef and Røst Reef (Sherwood et al., 2005). However, other factors have been documented, which seem to strongly influence 


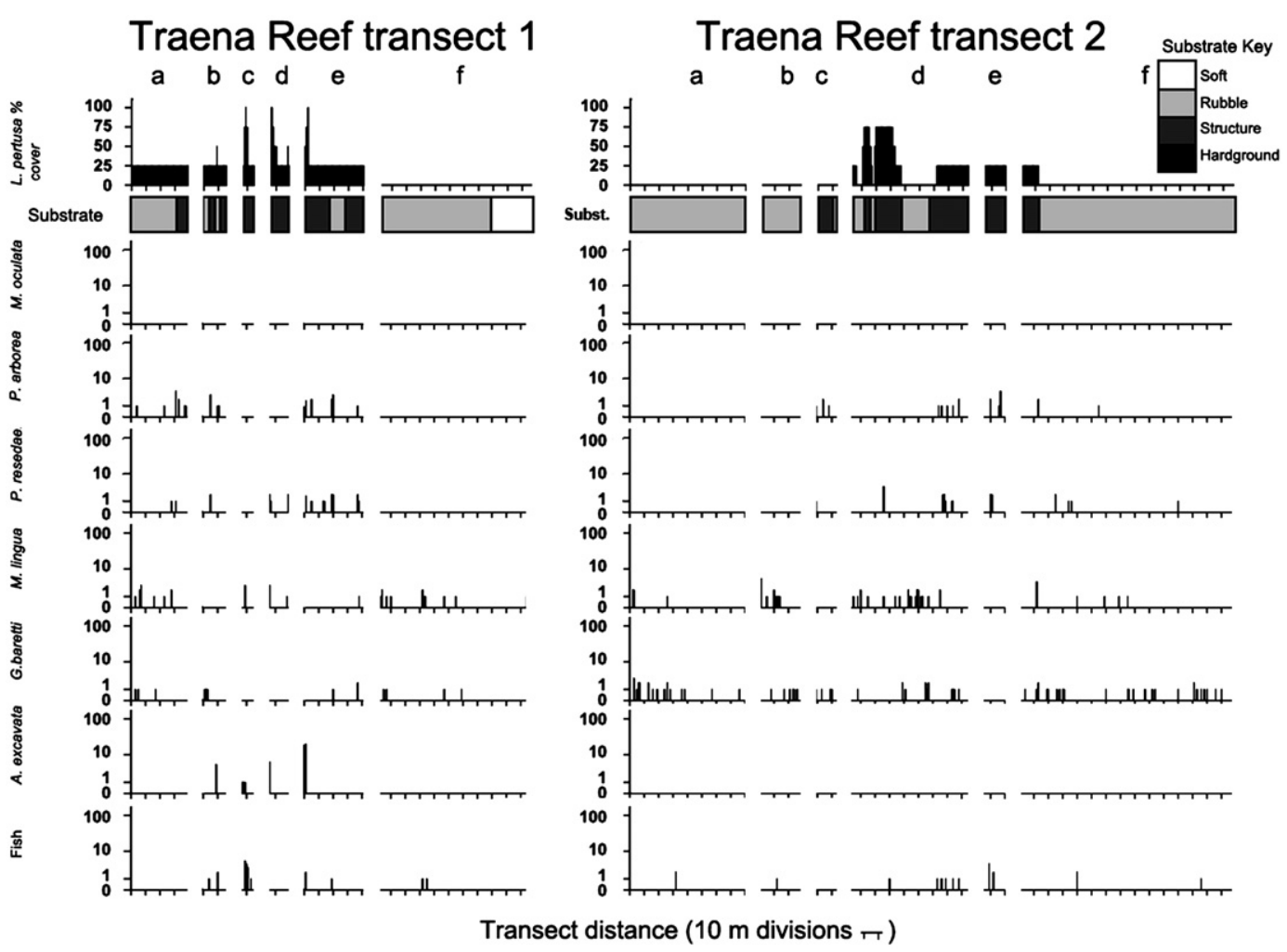

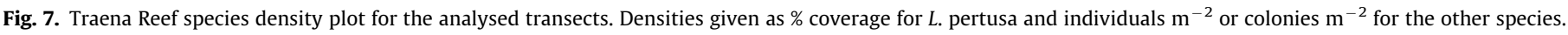
Letters represent the transect sections with usable video footage. Each division for the transect distance (x axis) corresponds to $10 \mathrm{~m}$.

the occurrence and distribution of this species (as well as that of $P$. arborea): bathymetric position index (BPI), slope, substrate rugosity and curvature (Tong et al. 2012).

\subsubsection{Mycale lingua}

The positive covariance between $M$. lingua and $L$. pertusa at Røst Reef and Sotbakken Reef but not at Traena Reef could indicate that although at Traena Reef much of the fresher material reaching the reef is collected by live $L$. pertusa and other species found in their highest densities at the upstream tip of each elongated reef structure. Food of sufficient quality and quantity for $M$. lingua growth passes downstream to the other reef regions. Such material could be the finer sized suspended material, $M$. lingua can use fine zooplankton as a food source $(<10 \mu \mathrm{m})$ (Pile et al., 1996), possibly too fine for efficient collection by species such as $L$. pertusa, dominant at the reef head.

\subsubsection{Geodia baretti}

G. baretti individuals generally had a random distribution across the various substrates (except for the clustering observed on soft sediments at Sotbakken Reef), with no sizable differences in density observed by reef or substrate, although a negative covariance with living $L$. pertusa was indicated. This possibly slow growing sponge species (Hoffmann et al., 2003) requires a hard substrate for attachment (individuals observed in soft sediment regions presumably attached to rocks or something solid such as shells or coral rubble within the sediment), but may not be able to compete with $L$. pertusa in speed of growth in regions suitable for coral colonisation.

\subsubsection{Acesta excavata}

One of the most striking differences between the reefs investigated was the near total absence of $A$. excavata from Røst Reef, despite the species being present in abundance at both Traena Reef and Sotbakken Reef. Highest abundances of $A$. excavata were most often recorded on the sides of coral structure blocks, on overhangs within the structure substrate or in grooves within and between coral colony blocks at these reefs (data not known), a tendency which has been observed at other CWC sites (López Correa et al., 2005; Huvenne et al., 2011). A. excavata are hypothesised to be adapted for regions with low, steady temperature and/or low or refractory food availability (Järnegren and Altin, 2006). Given the comparable temperatures observed at Røst Reef and Traena Reef during this study it is unlikely that any variation in temperature at other times of the year at these two neighbouring reefs could account for the high abundance of $A$. excavata at one and near absence from the other. Occurrence of $A$. excavata individuals at Traena Reef correlated closely with the peaks in $L$. pertusa coverage density (Fig. 7). This indicates that only the head sections of the Traena Reef elongated reef structures were suitable for successful colonisation and growth by the species. Potentially, colonisation of such upstream positions on the reef structure allows individuals to filter large volumes of suspended material from the unidirectional flow, acquiring a sufficient flux of (possibly low quality, refractory) food to flourish in such locations, and to outperform other species which may require a more labile carbon source. Alternatively, the colonisation of the upstream regions of the elongated reef structures at Traena Reef could give individuals the opportunity to filter any episodic fresh food deliveries (as may result from algal blooms, storm mixing etc.) before organisms situated further downstream the elongated structures get a chance at it. Both of these feeding strategies (utilisation of low quality food or utilisation of periodic high 
Table 2

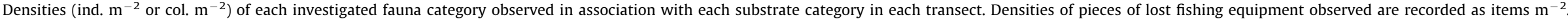
( $n=$ number of counted individuals in each transect for each substrate). L. pertusa is not included in this table as for this species \% coverage was calculated throughout each dive transect.

\begin{tabular}{|c|c|c|c|c|c|c|c|c|c|c|c|c|c|c|c|c|c|c|c|c|}
\hline \multirow[t]{2}{*}{ Transect } & \multirow[t]{2}{*}{ Length (m) } & \multirow[t]{2}{*}{ Substrate } & \multirow[t]{2}{*}{ Length (m) } & \multirow[t]{2}{*}{ Length (\%) } & \multicolumn{2}{|c|}{ M. Oculata } & \multicolumn{2}{|c|}{ P. arborea } & \multicolumn{2}{|c|}{ P. resedaeformis } & \multicolumn{2}{|c|}{ M. lingua } & \multicolumn{2}{|c|}{ Geodi baretti } & \multicolumn{2}{|c|}{ Acesta excavate } & \multicolumn{2}{|c|}{ Fish } & \multicolumn{2}{|c|}{ Anthropogenic } \\
\hline & & & & & $n$ & patches $\mathrm{m}^{-2}$ & $n$ & colonies $\mathrm{m}^{-2}$ & $n$ & colonies $\mathrm{m}^{-2}$ & $n$ & ind. $\mathrm{m}^{-2}$ & $n$ & ind. $\mathrm{m}^{-2}$ & $n$ & ind. $\mathrm{m}^{-2}$ & $n$ & ind. $\mathrm{m}^{-2}$ & $n$ & items $\mathrm{m}^{-2}$ \\
\hline \multirow[t]{5}{*}{ Rost 1} & 331 & & & & & & & & & & & & & & & & & & & \\
\hline & & Hardground & 0 & 0 & 0 & 0 & 0 & 0 & 0 & 0 & 0 & 0 & 0 & 0 & 0 & 0 & 0 & 0 & 0 & 0 \\
\hline & & Rubble & 204 & 62 & 0 & 0 & 1 & 0.003 & 2 & 0.007 & 106 & 0.346 & 90 & 0.294 & 0 & 0 & 12 & 0.004 & 0 & 0 \\
\hline & & Soft & 0 & 0 & 0 & 0 & 0 & 0 & 0 & 0 & 0 & 0 & 0 & 0 & 0 & 0 & 0 & 0 & 0 & 0 \\
\hline & & Structure & 127 & 38 & 0 & 0 & 20 & 0.105 & 6 & 0.031 & 147 & 0.772 & 12 & 0.063 & 0 & 0 & 33 & 0.017 & 0 & 0 \\
\hline \multirow[t]{5}{*}{ Rost 2} & 350 & & & & & & & & & & & & & & & & & & & \\
\hline & & Hardground & 15 & 4 & 0 & 0 & 5 & 0.222 & 6 & 0.267 & 0 & 0 & 0 & 0 & 0 & 0 & 0 & 0 & 0 & 0 \\
\hline & & Rubble & 66 & 19 & 6 & 0.061 & 26 & 0.263 & 11 & 0.111 & 14 & 0.141 & 7 & 0.071 & 0 & 0 & 0 & 0 & 0 & 0 \\
\hline & & Soft & 62 & 18 & 1 & 0.011 & 0 & 0 & 1 & 0.011 & 2 & 0.022 & 22 & 0.237 & 0 & 0 & 0 & 0 & 1 & 0.011 \\
\hline & & Structure & 207 & 59 & 1 & 0.003 & 111 & 0.357 & 78 & 0.251 & 130 & 0.419 & 4 & 0.013 & 1 & 0.003 & 15 & 0.005 & 0 & 0 \\
\hline Rost 3 & 340 & & & & & & & & & & & & & & & & & & & \\
\hline & & Hardground & 99 & 29 & 1 & 0.007 & 4 & 0.027 & 20 & 0.135 & 6 & 0.040 & 55 & 0.370 & 0 & 0 & 2 & 0.001 & 0 & 0 \\
\hline & & Rubble & 79 & 23 & 0 & 0 & 4 & 0.034 & 10 & 0.084 & 9 & 0.076 & 22 & 0.186 & 0 & 0 & 2 & 0.002 & 0 & 0 \\
\hline & & Soft & 0 & 0 & 0 & 0 & 0 & 0 & 0 & 0 & 0 & 0 & 0 & 0 & 0 & 0 & 0 & 0 & 0 & 0 \\
\hline & & Structure & 162 & 48 & 0 & 0 & 18 & 0.074 & 33 & 0.136 & 545 & 2.245 & 44 & 0.181 & 1 & 0.004 & 12 & 0.005 & 1 & 0.004 \\
\hline Rost 4 & 247 & & & & & & & & & & & & & & & & & & & \\
\hline & & Hardground & 25 & 10 & 0 & 0 & 4 & 0.107 & 6 & 0.160 & 0 & 0 & 0 & 0 & 0 & 0 & 0 & 0 & 0 & 0 \\
\hline & & Rubble & 137 & 55 & 1 & 0.005 & 83 & 0.404 & 20 & 0.097 & 17 & 0.083 & 29 & 0.141 & 0 & 0 & 10 & 0.005 & 0 & 0 \\
\hline & & Soft & 2 & 1 & 0 & 0 & 0 & 0 & 0 & 0 & 0 & 0 & 0 & 0 & 0 & 0 & 0 & 0 & 0 & 0 \\
\hline & & Structure & 83 & 34 & 1 & 0.008 & 31 & 0.249 & 44 & 0.353 & 65 & 0.522 & 12 & 0.096 & 0 & 0 & 10 & 0.008 & 0 & 0 \\
\hline Sotbak. 1 & 452 & & & & & & & & & & & & & & & & & & & \\
\hline & & Hardground & 0 & 0 & 0 & 0 & 0 & 0 & 0 & 0 & 0 & 0 & 0 & 0 & 0 & 0 & 0 & 0 & 0 & 0 \\
\hline & & Rubble & 62 & 14 & 0 & 0 & 0 & 0 & 0 & 0 & 2 & 0.022 & 7 & 0.075 & 0 & 0 & 11 & 0.012 & 0 & 0 \\
\hline & & Soft & 213 & 47 & 0 & 0 & 4 & 0.013 & 0 & 0 & 3 & 0.009 & 26 & 0.081 & 0 & 0 & 15 & 0.005 & 0 & 0 \\
\hline & & Structure & 177 & 39 & 0 & 0 & 72 & 0.271 & 11 & 0.041 & 38 & 0.143 & 5 & 0.019 & 333 & 1.254 & 65 & 0.025 & 0 & 0 \\
\hline Sotbak. 2 & 568 & & & & & & & & & & & & & & & & & & & \\
\hline & & Hardground & 0 & 0 & 0 & 0 & 0 & 0 & 0 & 0 & 0 & 0 & 0 & 0 & 0 & 0 & 0 & 0 & 0 & 0 \\
\hline & & Rubble & 0 & 0 & 0 & 0 & 0 & 0 & 0 & 0 & 0 & 0 & 0 & 0 & 0 & 0 & 0 & 0 & 0 & 0 \\
\hline & & Soft & 459 & 81 & 0 & 0 & 0 & 0 & 0 & 0 & 7 & 0.007 & 76 & 0.074 & 0 & 0 & 35 & 0.003 & 0 & 0 \\
\hline & & Structure & 109 & 19 & 0 & 0 & 29 & 0.118 & 5 & 0.020 & 25 & 0.102 & 14 & 0.057 & 566 & 2.307 & 42 & 0.017 & 0 & 0 \\
\hline Sotbak. 3 & 345 & & & & & & & & & & & & & & & & & & & \\
\hline & & Hardground & 0 & 0 & 0 & 0 & 0 & 0 & 0 & 0 & 0 & 0 & 0 & 0 & 0 & 0 & 0 & 0 & & \\
\hline & & Rubble & 170 & 49 & 0 & 0 & 4 & 0.016 & 3 & 0.012 & 4 & 0.016 & 5 & 0.020 & 0 & 0 & 79 & 0.031 & 0 & 0 \\
\hline & & Soft & 175 & 51 & 0 & 0 & 5 & 0.019 & 0 & 0 & 3 & 0.011 & 3 & 0.011 & 0 & 0 & 16 & 0.006 & 0 & 0 \\
\hline & & Structure & 0 & 0 & 0 & 0 & 0 & 0 & 0 & 0 & 0 & 0 & 0 & 0 & 0 & 0 & 0 & 0 & 0 & 0 \\
\hline Traena 1 & 227 & & & & & & & & & & & & & & & & & & & \\
\hline & & Hardground & 0 & 0 & 0 & 0 & 0 & 0 & 0 & 0 & 0 & 0 & 0 & 0 & 0 & 0 & 0 & 0 & 0 & 0 \\
\hline & & Rubble & 118 & 52 & 0 & 0 & 9 & 0.051 & 5 & 0.028 & 21 & 0.119 & 10 & 0.056 & 5 & 0.028 & 3 & 0.002 & 1 & 0.006 \\
\hline & & Soft & 31 & 14 & 0 & 0 & 0 & 0 & 0 & 0 & 1 & 0.022 & 0 & 0 & 0 & 0 & 0 & 0 & 0 & 0 \\
\hline & & Structure & 78 & 34 & 0 & 0 & 20 & 0.171 & 16 & 0.137 & 8 & 0.068 & 3 & 0.026 & 48 & 0.410 & 18 & 0.015 & 5 & 0.043 \\
\hline Traena 2 & 368 & & & & & & & & & & & & & & & & & & & \\
\hline & & Hardground & 0 & 0 & 0 & 0 & 0 & 0 & 0 & 0 & 0 & 0 & 0 & 0 & 0 & 0 & 0 & 0 & 0 & 0 \\
\hline & & Rubble & 273 & 74 & 0 & 0 & 6 & 0.015 & 2 & 0.005 & 36 & 0.088 & 57 & 0.139 & 0 & 0 & 6 & 0.002 & 0 & 0 \\
\hline & & Soft & 0 & 0 & 0 & 0 & 0 & 0 & 0 & 0 & 0 & 0 & 0 & 0 & 0 & 0 & 0 & 0 & 0 & 0 \\
\hline & & Structure & 95 & 26 & 0 & 0 & 17 & 0.119 & 16 & 0.112 & 11 & 0.077 & 12 & 0.084 & 0 & 0 & 12 & 0.008 & 1 & 0.007 \\
\hline
\end{tabular}




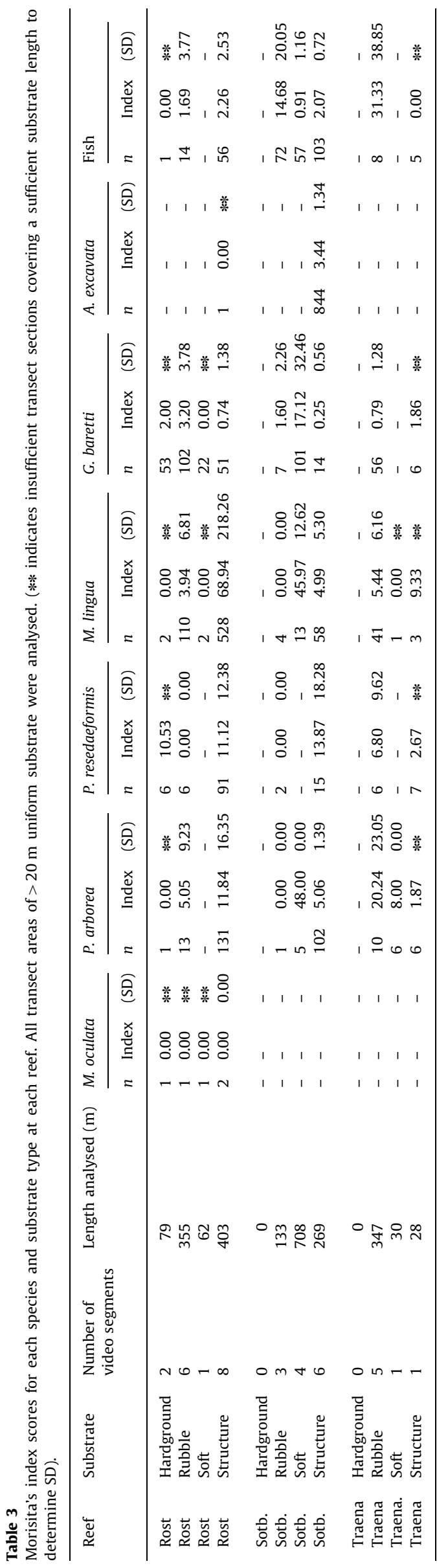

quality food inputs) have been observed by L. pertusa in other locations (Davies et al., 2009; Mienis et al., 2009; Van Oevelen et al., 2009; Wagner et al., 2011) and under different nutrient availability regimes (Kiriakoulakis et al., 2005), possibly explaining the high densities of the scleractinian coral only at the upstream tips of these reef structures. Given the co-occurrence of the highest densities of $A$. excavata with high densities of $L$. pertusa, the two species could be using the same feeding strategies at Traena Reef, or possibly be the most successful two investigated species in collecting food in the high flow, unidirectional current conditions reported for the location, but feeding on different sized material ( $L$. pertusa on the larger, $A$. excavata on the smaller suspended material fractions). The pattern of $A$. excavata distribution at Sotbakken Reef is however very different. The near absence of $A$. excavata from Røst Reef may indicate that at that location, the exposed structure substrate is swiftly overgrown by young $L$. pertusa coral polyps, which are possibly able to grow at a swifter rate than $A$. excavata, given a hypothesised fresher nutrient supply being available at that reef. At the northerly Sotbakken Reef temperatures recorded during the survey dives were $1^{\circ} \mathrm{C}$ lower than those recorded at the other two reefs. Järnegren and Altin (2006) showed that A. excavata is capable of filtering a large volume of water whilst maintaining a low respiration rate at low temperatures. Metabolism in $L$. pertusa is highly temperature dependant (Dodds et al., 2007; Brooke et al., in press), Potentially, the ability of $A$. excavata to function well under low temperatures allows them to colonise dead coral structure more preferentially than $L$. pertusa in northerly Norwegian reefs exposed to generally colder waters. A. excavata has also been observed in high abundance in association with smaller, less developed $L$. pertusa structures at the Mid-Atlantic Ridge (Mortensen et al., 2008), again indicating that this species may only be able to establish itself amongst living $L$. pertusa coral structure when conditions are not optimal for rapid $L$. pertusa colony development.

\subsubsection{Fish}

The importance of CWC reefs as fish habitats has been a subject of discussion throughout the last ten years (Auster, 2005; Fosså and Skjoldal, 2010; Murillo et al., 2011). Husebø et al. (2002) investigated the abundance of individual fish species across various reef substrate types. In this study we made no attempt to differentiate fish by species. We observed a greater density of total fish numbers above and within the structure substrate category than above outcroppings of hardground, rubble or soft sediments. A higher density of fish was present at both the Røst Reef and Sotbakken Reef than at Traena Reef (average fish densities recorded across all substrate categories combined). This observation, given the more extensive and complex Røst Reef and Sotbakken Reef structures, supports the argument that fish are present in generally higher densities at developed reef sites (D'Onghia et al., 2012), and that these densities are not exclusively found in association with the areas of coral structure substrate but throughout the environment surrounding such structures as well. The higher fish numbers recorded in this study across these reefs could be the result of generally higher food availability in the waters surrounding the reefs, as a result of increased turbulence or physical drawdown processes (Wagner et al., 2011). Also attractive to fish may be the elevated local concentrations of zooplankton often observed at reefs (Mortensen, 2001; Kiriakoulakis et al., 2004). Additionally, both zooplankton and phytoplankton may be aggregated with suspended coral mucus, commonly found in suspension within and downstream of the reef environment (Wild et al., 2008; Wagner et al., 2011). Also of use to fish may be the high physical habitat complexity offered by these two shelf edge reefs (a typically 
Table 4

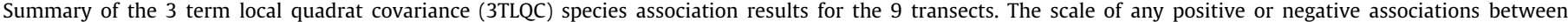

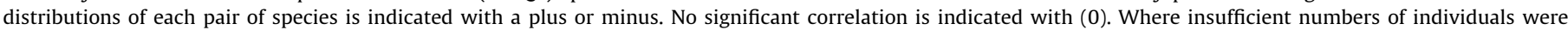

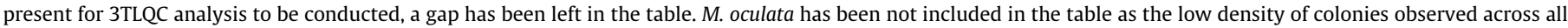
reefs rendered 3TLQC analysis impossible.

\begin{tabular}{|c|c|c|c|c|c|c|c|c|c|}
\hline Species & Reef transect & & & & & & & & \\
\hline Compared & Rost 1 & Rost 2 & Rost 3 & Rost 4 & Sotb 1 & Sotb 2 & Sotb 3 & Traena 1 & Traena 2 \\
\hline L. pertusa/P. arborea & $(+) 12-58$ & $\begin{array}{l}(+) 6-22 \\
(+) 38-120\end{array}$ & $\begin{array}{l}(-) \text { 5-12 } \\
(+) 19-37 \\
(+) 90-104\end{array}$ & $\begin{array}{l}(+) \text { 5-10 } \\
(+) 23-72\end{array}$ & $(+) 42-142$ & $(+) 77-200$ & & $\begin{array}{l}(+) 7-14 \\
(+) 42-54 \\
(62-80)\end{array}$ & $\begin{array}{l}(-) \text { 29-75 } \\
(+) \text { 84-135 }\end{array}$ \\
\hline L. pertusa/P. resedaeformis & $(+) 10-69$ & $(+)$ 59-99 & $\begin{array}{l}(+) \text { 27-60 } \\
(-) 73-109\end{array}$ & $(+) 30-75$ & $\begin{array}{l}(+) 25-52 \\
(+) 114-137\end{array}$ & $(+) 80-200$ & & $(+) 13-88$ & $\begin{array}{l}(+) 9-33 \\
(+) 59-135\end{array}$ \\
\hline L. pertusa/M. lingua & $(+)$ 10-102 & $(+)$ 30-107 & $(+) 8-109$ & $\begin{array}{l}(+) 18-44 \\
(-) 53-78\end{array}$ & $(+) 60-137$ & $\begin{array}{l}(-) \text { 5-20 } \\
(+) \text { 65-200 }\end{array}$ & & $(-) 38-78$ & $\begin{array}{l}(-) \text { 12-33 } \\
(+) 62-135\end{array}$ \\
\hline L. pertusa/G. baretti & $\begin{array}{l}(-) \text { 20-56 } \\
(-) 86-102\end{array}$ & $(-)$ 30-120 & $\begin{array}{l}(-) \text { 26-42 } \\
(-) \text { 89-109 }\end{array}$ & $\begin{array}{l}(+) \text { 5-10 } \\
(-) 35-58\end{array}$ & $(-)$ 80-145 & $(-) 75-200$ & & $(-)$ 50-70 & $\begin{array}{l}(-) 18-57 \\
(-) 116-135\end{array}$ \\
\hline L. pertusa/A. excavata & & & & & $(+) 35-160$ & $\begin{array}{l}(-) \text { 5-18 } \\
(+) \text { 50-200 }\end{array}$ & & $\begin{array}{l}(+) 3-15 \\
(-) 20-37 \\
(+) 47-84\end{array}$ & \\
\hline L. pertusa/Fish & $\begin{array}{l}(-) \text { 11-20 } \\
(+) 24-102\end{array}$ & $(+) 30-120$ & $\begin{array}{l}(+) \text { 34-60 } \\
(-) \text { 70-102 }\end{array}$ & $(0)$ & $(+)$ 65-145 & $\begin{array}{l}(+) 14-30 \\
(+) 65-125 \\
(-) 138-162\end{array}$ & & $\begin{array}{l}(+) 3-10 \\
(+) 19-37 \\
(-) 65-88\end{array}$ & $\begin{array}{l}(-) \text { 42-52 } \\
(+) 83-135\end{array}$ \\
\hline P. arborea/P. resedaeformis & $\begin{array}{l}(+) \text { 4-19 } \\
(+) 32-53\end{array}$ & $(+) 5-17$ & $(-)$ 63-77 & $(+) 32-86$ & $(-)$ 18-36 & & & $(+) 7-10$ & $\begin{array}{l}(+) 11-20 \\
(+) 58-133\end{array}$ \\
\hline P. arborea/M. lingua & $(+) 5-57$ & $(+) 6-20$ & $\begin{array}{l}(-) 7-13 \\
(+) 18-30 \\
(-) 46-90\end{array}$ & $\begin{array}{l}(-) 17-28 \\
(-) 47-86\end{array}$ & $\begin{array}{l}(-) 8-13 \\
(+) 67-123\end{array}$ & $\begin{array}{l}(+) 20-30 \\
(+) 157-200\end{array}$ & $(-)$ 6-11 & $(-)$ 24-56 & $\begin{array}{l}(-) \text { 17-72 } \\
(+) 98-133\end{array}$ \\
\hline P. arborea/G. baretti & (0) & $(0)$ & $\begin{array}{l}(-) \text { 12-35 } \\
(+) 78-85\end{array}$ & & $(0)$ & $(-)$ 85-168 & $(0)$ & $(0)$ & (-) 127-133 \\
\hline P. arborea/A. excavate & & & & & $(+) 85-122$ & $(+) 85-200$ & $(+) 7-13$ & & \\
\hline P. arborea/Fish & (0) & $(+)$ 58-102 & $(0)$ & $(-) 69-86$ & $(0)$ & $(+)$ 12-35 & $(+) 11-25$ & $(-)$ 33-60 & $\begin{array}{l}(+) 10-18 \\
(+) 34-133\end{array}$ \\
\hline P. resedaeformis/M. lingua & $(+)$ 10-63 & $(+) 2-18$ & $(+) 23-74$ & $\begin{array}{l}(+) 9-18 \\
(-) 36-86\end{array}$ & $(-)$ 44-54 & & & $(0)$ & $\begin{array}{l}(-) \text { 13-34 } \\
(+) 90-133\end{array}$ \\
\hline P. resedaeformis/G. baretti & $(-)$ 31-44 & $(0)$ & $(0)$ & $\begin{array}{l}(-) 2-4 \\
(+) 7-67\end{array}$ & $(0)$ & & & $(0)$ & $(-)$ 125-133 \\
\hline P. resedaeformis/A. excavate & & & & & $\begin{array}{l}(-) 20-38 \\
(-) 120-155\end{array}$ & & & $\begin{array}{l}(+) 6-10 \\
(-) 15-21\end{array}$ & \\
\hline P. resedaeformis/Fish & $(+) 36-52$ & (0) & $(0)$ & $(0)$ & $(-)$ 118-145 & & & $(-)$ 33-88 & $(+) 5-133$ \\
\hline M. lingua/G. baretti & $\begin{array}{l}(+) 7-15 \\
(-) 22-50 \\
(-) 77-111\end{array}$ & $\begin{array}{l}(0) \\
(0)\end{array}$ & $\begin{array}{l}(-) \text { 23-51 } \\
(-) 64-122\end{array}$ & $(-) 76-86$ & $(-)$ 98-121 & $(0)$ & $(0)$ & $(0)$ & $\begin{array}{l}(+) 29-43 \\
(-) 126-133\end{array}$ \\
\hline M. lingua/A. excavata & & & & & $(+)$ 20-135 & $\begin{array}{l}(+) 6-30 \\
(+) 87-200\end{array}$ & & $(-)$ 27-74 & \\
\hline M. lingua/Fish & $(-) 12-22$ & $(0)$ & $\begin{array}{l}(-) \text { 10-18 } \\
(+) 30-63\end{array}$ & $\begin{array}{l}(+) 4-10 \\
(-) 18-26 \\
(+) 71-86\end{array}$ & $\begin{array}{l}(-) 2-8 \\
(+) 24-55 \\
(+) 87-127\end{array}$ & $(+) 20-32$ & $(0)$ & $(0)$ & $\begin{array}{l}(-) \text { 24-53 } \\
(+) 99-133\end{array}$ \\
\hline G. baretti/A. excavata & & & & & $\begin{array}{l}(+) \text { 27-67 } \\
(-) 85-160\end{array}$ & $(-)$ 87-172 & & $(-)$ 33-67 & \\
\hline G. baretti/Fish & $(-)$ 29-43 & $(0)$ & $(-)$ 6-18 & $(0)$ & $(-)$ 90-157 & $(-)$ 15-45 & $(0)$ & $\begin{array}{l}(-) \text { 18-26 } \\
(-) 49-65\end{array}$ & $\begin{array}{l}(-) \text { 22-36 } \\
(-) 127-133\end{array}$ \\
\hline $\begin{array}{l}\text { A. excavata/ } \\
\text { Fish }\end{array}$ & & & & & $(+) 15-160$ & $(+) 80-112$ & & $\begin{array}{l}(-) 30-45 \\
(-) 72-85\end{array}$ & \\
\hline
\end{tabular}

observed utilisation of structure by Brosme brosme is given in Fig. 3h).

\section{Conclusions}

Differences in abundance of many of the fauna investigated were apparent between reefs, as were trends in species covariance observed at each reef. Although only a small selection of the numerous reef species thus far reported from European CWC reefs (Hovland, 2008; Henry et al., 2010; Mastrototaro et al., 2010) were included in this study, it is quite possible that other species may vary in abundance between reefs to a similar degree. Certainly the abundances of fauna closely associated with the investigated species, such as the arthropod communities supported by the gorgonians (Buhl-Mortensen and Mortensen, 2004) or the polychaete Eunice norvegica, often symbiotic with $L$. pertusa
(Roberts, 2005) will vary in abundance with the change in density of their associated fauna species.

Fish abundances observed during the survey transects varied with respect to both substrate type and reef, but were generally higher in areas of substrate of biogenic origin (coral rubble and coral structure substrate categories) than those unrelated to reef presence/absence (hardground and soft sediment categories).

From this study, it is clear that community structure varies significantly between CWC reefs on the Norwegian margin. Management plans for such areas should therefore not be based on the assumption that all areas of the seabed labelled as 'Coldwater coral ecosystem' are comparable and interchangeable in morphology, species composition or population density. Reefs with broadly similar live $L$. pertusa coverage (such as at Røst Reef and Sotbakken Reef in this study) can clearly have quite different associate fauna populations. 


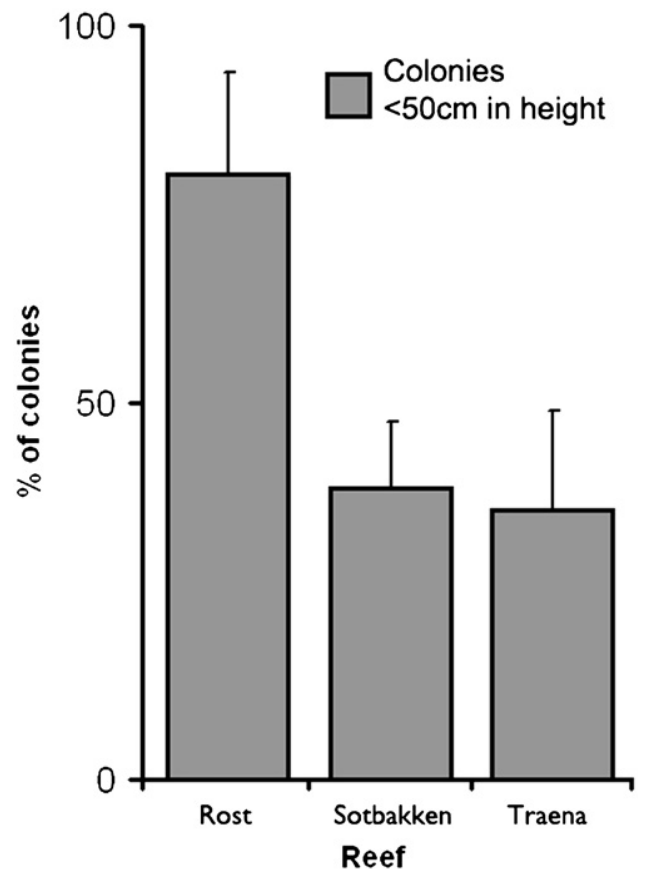

Fig. 8. $P$. arborea colony sizes ( $<50 \mathrm{~cm}$ or $>50 \mathrm{~cm}$ height categories) observed at each reef. Error bars represent $1 \mathrm{SD}$.

\section{Acknowledgements}

The research leading to these results has received funding from the European Community's Seventh Framework Programme (FP7/2007-2013) under the HERMIONE project, grant agreement $\mathrm{n}^{\circ}$ 226354), Statoil and is a CORAMM group collaboration. The captain, crew and on-board scientific party of RV Polarstern ARKXXII/1a cruise are thanked for their assistance, particularly the IFM-GEOMAR JAGO team who provided access to the video data used in this paper. In the first stage of the development of this manuscript, C. Orejas and A. Gori were supported by a post doctoral and Ph.D. I3P contracts, respectively, (Ref. I3P-PC2006L, I3P-BPD2005) from the Consejo Superior de Investigaciones Científicas (CSIC). We would like to thank two anonymous reviewers whose comments allowed us to greatly improve this manuscript.

\section{References}

Andrews, A.H. Cordes, E.E., Mahoney, M.M. 2002. Age, growth and radiometric age validation of a deep-sea, habitat-forming gorgonian (Primnoa resedaeformis) from the Gulf of Alaska. Hydrobiologica 471, 101-110.

Armstrong, C.W., Grehan, A.J., Kahui, V., Mikkelsen, E., Reithe, S., Van Den Hove, S 2009. Bioeconomic modelling and the management of cold-water coral resources. Oceanography 22, 86-91.

Auster, P.J., 2005. Are deep-water corals important habitats for fish?. In: Freiwald, A., Roberts, J.M. (Eds.), Cold-Water Corals and Ecosystems. Springer, Berlin, pp. 747-760.

Baker, K.D., Wareham, V.E., Snelgrove, P.V.R., Haedrich, R.L., Fitfield, D.A., Edinger E.N., Gilkinson, K.D., 2012. Distributional patterns of deep-sea coral assemblages in three submarine canyons off Newfoundland, Canada. Marine Ecology Progress Series 445, 235-249.

Brooke, S., Ross, S.W., Young, C.M. Temperature tolerance of the deep-sea coral Lophelia pertusa from the southeastern United States. Deep Sea Research Part II: Topical Studies in Oceanography, in press. http://dx.doi.org/10.1016/j.dsr2. 2012.12.001, in press.

Bryan, T.L., Metaxas, A., 2007. Predicting suitable habitat for deep-water gorgonian corals on the Atlantic and Pacific continental margins of North America. Marine Ecology Progress Series 330, 113-126.

Buhl-Mortensen, L., Mortensen, P.B., 2004. Crustaceans associated with the deepwater gorgonian Paragorgia arborea (L., 1758) and Primnoa resedaeformis (Gunnerus, 1763). Journal of Natural History 38, 1233-1247.
Buhl-Mortensen, L., Vanreusel, A., Gooday, A.J., Levin, L.A., Priede, I.G., Buhl-Mortensen, P.B., Gheerardyn, H., King, N.J., Raes, M., 2010. Biological structures as a source of habitat heterogeneity and biodiversity on the deep ocean margins. Marine Ecology an Evolutionary Perspective 31, 21-50.

Clark, M.R., Rowden, A.A., 2009. Effects of deepwater trawling on the macroinvertebrate assemblages of seamounts on the Chatham Rise, New Zealand. Deep Sea Research Part I: Oceanographic Research Papers 56, 1540-1544.

Clark, M.R., Tittensor, D.P., 2010. An index to assess the risk to stony corals from bottom trawling on seamounts. Marine Ecology 31, 200-211.

Clark, M.R., Rowden, A.A., Schlacher, T., Williams, A., Consalvey, M., Stocks, K.I., Rogers, A.D., O'Hara, T.D., White, M., Shank, T.M., Hall-Spencer, J., 2010. The Ecology of seamounts: Structure, function, and human impacts. Annual Review of Marine Science 2, 253-278.

Cordes, E.E., McGinley, M.P., Podowski, E.L., Becker, E.L., Lessard-Pilon, S., Viada, S.T., Fisher, C.R., 2008. Coral communities of the deep Gulf of Mexico. Deep Sea Research Part I: Oceanographic Research Papers 55, 777-787.

Costello, M., McCrea, M., Freiwald, A., Lundälv, T., Jonsson, L., Bett, B., Weering, T. Haas, H., Roberts, J., Allen, D., 2005. Role of cold-water Lophelia pertusa coral reefs as fish habitat in the NE Atlantic. In: Freiwald, A., Roberts, J.M. (Eds.), Cold-Water Corals and Ecosystems. Springer, Berlin, pp. 771-805.

Dale, M.R.T., 1999. Basic methods for one dimension and one species. In: Dale, M.R.T. (Ed.), Spatial Pattern Analysis in Plant Ecology. Cambridge University Press, Cambridge, pp. 50-99.

Damuth, J.E., 1978. Echo character of Norwegian-Greenland Sea: relationship to Quaternary Sedimentation. Marine Geology 28, 1-36.

Davies, A.J., Wisshak, M., Orr, J.C., Roberts, J.M., 2008. Predicting suitable habitat for the cold-water coral Lophelia pertusa (Scleractinia). Deep Sea Research Part I: Oceanographic Research Papers 55, 1048-1062.

Davies, A.J., Duineveld, G.C.A., Lavaleye, M.S.S., Bergman, M.J.N., van Haren, H., Roberts, J.M., 2009. Downwelling and deep-water bottom currents as food supply mechanisms to the cold-water Lophelia pertusa (Scleractinia) at the Mingulay Reef complex. Limnology and Oceanography 54 (2), $620-629$.

De Mol, B., Van Rensbergen, P., Pillen, S., Van Herreweghe, K., Van Rooij, D. McDonnell, A., Huvenne, V., Ivanov, M., Swennen, R., Henriet, J.P., 2002. Large deep-water coral banks in the Porcupine Basin, southwest of Ireland. Marine Geology 188, 193-231.

Dodds, L.A., Roberts, J.M., Taylor, A.C., Marubini, F., 2007. Metabolic tolerance of the cold-water coral Lophelia pertusa (Scleractinia) to temperature and dissolved oxygen change. Journal of Experimental Marine Biology and Ecology 349, 205-214.

Dolan, M.F.J., Grehan, A.J., Guinan, J.C., Brown, C., 2008. Modelling the local distribution of cold-water corals in relation to bathymetric variables: Adding spatial context to deep-sea video data. Deep Sea Research Part I: Oceanographic Research Papers 56, 1564-1579.

D’Onghia, G., Maiorano, P., Sion Giove, L.A., Capezzuto, F.R., Carlucci, R., Tursi, A., 2010. Effects of deep-water coral banks on the abundance and size structure of the megafauna in the Mediterranean Sea. Deep Sea Research Part II: Topical Studies in Oceanography 57, 397-411.

D’Onghia, G., Maiorano, P., Carlucci, R., Capezzuto, F., Carluccio, A., Tursi, A., Sion, L., 2012. Comparing deep-sea fish fauna between coral and non-coral "megahabitats" in the Santa Maria di Leuca cold-water coral province (Mediterranean Sea). PLoS ONE 7 (9), e44509, http://dx.doi.org/10.1371/journal. pone.0044509.

Dorschel, B., Hebbeln, D., Rüggeberg A., Dullo, W.C., Freiwald, A., 2005. Growth and erosion of a cold-water coral covered carbonate mound in the Northeast Atlantic during the Late Pleistocene and Holocene. Earth and Planetary Science Letters 233, 33-44.

Duineveld, G.C.A., Lavaleye, M.S.S., Berghuis, E.M., 2004. Particle flux and food supply to a seamount cold-water coral community (Galicia Bank, NW Spain). Marine Ecology Progress Series 277, 13-23.

Duineveld, G.C.A., Lavaleye, M.S.S., Bergman, M.J.N., de Stigter, H., Mienis, F., 2007. Trophic structure of a cold-water coral mound community (Rockall Bank, NE Atlantic) in relation to the near-bottom particle supply and current regime. Bulletin of Marine Science 81, 449-467.

Duineveld, G.C.A., Jeffreys, R.M., Lavaleye, M.S.S., Davies, A.J., Bergman, M.J.N., Watmough, T., Witbaard, R., 2012. Spatial and tidal variation in food supply to shallow cold-water coral reefs of the Mingulay Reef complex (Outer Hebrides, Scotland). Marine Ecology Progress Series 444, 97-115.

Dullo, W.C., Flögel, S., Rüggeberg, A., 2008. Cold-water coral growth in relation to the hydrography of the Celtic and Nordic European continental margin. Marine Ecology Progress Series 371, 165-176.

Edinger, E.N., Wareham, V.E., Haedrich, R.L., 2007. Patterns of groundfish diversity and abundance in relation to deep-sea coral distributions in Newfoundland and Labrador waters. Bulletin of Marine Science 81, 101-122.

Fosså, J.H., 2005. Cruise report R/V G.O. Sars cruise No. 2005108. Institute of Marine Research, Norway.

Fosså, J.H., Skjoldal, H.R., 2010. Conservation of cold-water coral reefs in Norway. In: Grafton, R.Q., Hilborn, R., Squires, D., Tait, M., Williams, M. (Eds.), Handbook of Marine Fisheries Conservation and Management. Oxford University Press, US, pp. 215-240.

Fosså, J.H., Mortensen, P.B., Furevik, D.M., 2000. Lophelia-korallrev langs norskekysten forekomst og tilstand. Fisken og Havet 2, 1-94.

Fosså, J.H., Mortensen, P.B., Furevik, D.M., 2002. The deep-water coral Lophelia pertusa in Norwegian waters: distribution and fishery impacts. Hydrobiologia $471,1-12$. 
Fosså, J.H., Lindberg, B., Christensen, O., 2005. Mapping of Lophelia reefs in Norway: experiences and survey methods. In: Freiwald, A., Roberts, J.M. (Eds.), Cold-Water Corals and Ecosystems. Springer, Berlin, pp. 359-391.

Frank, N., Ricard, E., Lutringer-Paquet, A., van der Land, C., Colin, C., Blamart, D., Foubert, A., Van Rooij, D., Henriet, J.-P., de Hass, H., van Weering, T., 2009. The Holocene occurence of cold water corals in the NE Atlantic: Implications for coral carbonate mound evolution. Marine Geology 266, 129-142.

Freiwald, A., Wilson, J.B., 1998. Taphonomy of modern deep, cold-temperate water coral reefs. Historical Biology 13, 37-52.

Freiwald, A., Wilson, J.B., Henrich, R., 1999. Grounding Pleistocene icebergs shape recent deep-water corals. Sedimentary Geology 125, 1-8.

Freiwald, A., Hühnerbach, V., Lindberg, B., Wilson, J.B., Campbell, J., 2002. The Sula Reef Complex, Norwegian shelf. Facies 47, 179-200.

Gagnon, J.M., Haedrich, R.L., 2003. First record of the European Giant File Clam, Acesta excavata (Bivalvia: Pectinoidea: Limidae), in the Northwest Atlantic. The Canadian Field-Naturalist 117, 440-447.

Gilmour, T.H.J., 1990. The adaptative significance of foot reversal in the Limoida. In: Morton, B. (Ed.), The Bivalvia-Proceedings of a Memorial Symposium in Honour of Sir Charles Maurice Yonge. Hong Kong University Press, Hong Kong, pp. 249-264.

Gordon, J.D.M., 2001. Deep-water fisheries at the Atlantic Frontier. Continental Shelf Research 21, 987-1003.

Gori, A., Rossi, S., Berganzo, E., Pretus, J.L., Dale, M.R.T., Gili, J.M., 2011a. Spatial distribution patterns of the gorgonians Eunicella singularis, Paramuricea clavata, and Leptogorgia sarmentosa (Cape of Creus, Northwestern Mediterranean Sea). Marine Biology 158, 143-158.

Gori, A., Rossi, S., Linares, C., Berganzo, E., Orejas, C., Dale, M.R.T., Gili, J.M., 2011b. Size and spatial structure in deep versus shallow populations of the Mediterranean gorgonian Eunicella singularis (Cap de Creus, northwestern Mediterranean Sea). Marine Biology 158, 1721-1732.

Guinan, J., Grehan, A.J., Dolan, M.F.J., Brown, C., 2009. Quantifying relationships between video observations of cold-water coral cover and seafloor features in Rockall Trough, west of Ireland. Marine Ecology Progress Series 375, 125-138.

Hall-Spencer, J.M., Tasker, M., Soffker, M., Christiansen, S., Rogers, S., Campbell, M., Hoydal, K., 2008. Design of marine protected areas on high seas and territorial waters of rockall Bank. Marine Ecology Progress Series 397, 305-308.

Hattori, A., Kobayashi, M., 2009. Incorporating fine-scale seascape composition in an assessment of habitat quality for the giant sea anemone Stichodactyla gigantea in a coral reef shore zone. Ecological Research 24, 415-422.

Henry, L.A., 2001. Hydroids associated with deep-sea corals in the boreal northwest Atlantic. Journal of the Marine Biological Association of the UK 81, $163-164$.

Henry, L.A., Roberts, J.M., 2007. Biodiversity and ecological composition of macrobenthos on cold-water coral mounds and adjacent off-mound habitat in the bathyal Porcupine Seabight, NE Atlantic. Deep Sea Research Part I: Oceanographic Research Papers 54, 654-672.

Henry, L.A., Davies, A.J., Roberts, J.M., 2010. Beta diversity of cold-water coral reef communities off western Scotland. Coral Reefs 29, 427-436.

Hoffmann, F., Rapp, H.T., Zöller, T., Reitner, J., 2003. Growth and regeneration in cultivated fragments of the boreal deep water sponge Geodia baretti Bowerbank, 1858 (Geodiidae, Tetractinellida, Demospongiae). Journal of Biotechnology $100,109-118$

Hovland, M., 2005. Pockmark-associated coral reefs at the Kristin field off Mid-Norway. In: Freiwald, A., Roberts, J.M. (Eds.), Cold-Water Corals and Ecosystems. Springer, Berlin, pp. 623-632.

Hovland, M., 2008. Deep-Water Coral Reefs, Unique Biodiversity Hot-Spots. Praxis publishing ltd, Chichester, UK.

Husebø, A., Nøttestad, L., Fosså, J.H., Furevik, D.M., Jørgensen, S.B., 2002. Distribution and abundance of fish in deep-sea coral habitats. Hydrobiologica 471, 91-99.

Huvenne, V.A.I., Tyler, P.A., Masson, D.G., Fisher, E.H., Hauton, C., Hühnerbach, V. Le Bas, T.P., Wolff, G.A., 2011. A picture on the wall: innovative mapping reveals cold-water coral refuge in submarine canyon. PLoS ONE 6 (12), e28755, http://dx.doi.org/10.1371/journal.pone.0028755.

Järnegren, J., Altin, D., 2006. Filtration and respiration of the deep living bivalve Acesta excavata (J.C. Fabricius, 1779) (Bivalvia; Limidae). Journal of Experimental Marine Biology and Ecology 334, 122-129.

Jensen, A., Frederiksen, R., 1992. The fauna associated with the bank-forming deepwater coral Lophelia pertusa (Scleractinaria) on the Faroe shelf. Sarsia 77, 53-69.

Jonsson, L.G., Nilsson, P.G., Floruta, F., Lundälv, T., 2004. Distributional patterns of macro- and megafauna associated with a reef of the cold-water coral Lophelia pertusa on the Swedish west coast. Marine Ecology Progress Series 284, 163-171.

Kenyon, N.H., Akhmetzhanov, A.M. Wheeler, AJ., van Weering T.C.E., de Hass, H. Ivanov, M.K., 2003. Giant carbonate mud mounds in the southern Rockall Trough. Marine Geology 195, 5-30.

Kiriakoulakis, K., Bett, B.J., White, M., Wolff, G.A., 2004. Organic biogeochemistry of the Darwin Mounds, a deep-water coral ecosystem, of the NE Atlantic. Deep Sea Research Part I: Oceanographic Research Papers 51, 1937-1954.

Kiriakoulakis, K., Fisher, E., Wolff, G.A., Freiwald, A., Grehan, A., Roberts, J.M., 2005. Lipids and nitrogen isotopes of two deep-water corals from the North-East Atlantic: initial results and implications for their nutrition. In: Freiwald, A., Roberts, J.M. (Eds.), Cold-Water Corals and Ecosystems. Springer, Berlin, pp. 715-729.
Kiriakoulakis, K., Freiwald, A., Fisher, E., Wolff, G.A., 2007. Organic matter quality and supply to deep-water coral/mound systems of the NW European Continental margin. International Journal of Earth Sciences 96, 159-170.

Klages, M., Thiede, J., 2011. The Expedition of the Research Vessel "Polarstern" to the Arctic in 2007 (ARK-XXII/1a-c) Berichte zur Polar- und Meeresforschung (Reports on Polar and Marine Research), Bremerhaven, Alfred Wegener Institute for Polar and Marine Research.

Klitgaard, A.B., Tendal, O.S., 2004. Distribution and species composition of mass occurrences of large-sized sponges in the northeast Atlantic. Progress in Oceanography 61, 57-98.

Krieger, K.J., 1993. Distribution and abundance of rockfish determined from a submersible and by bottom trawling. Fisheries Bulletin 91, 87-96.

Krieger, K.J., Wing, B.L., 2002. Megafauna associations with deepwater corals (Primnoa spp.) in the Gulf of Alaska. Hydrobiologica 471, 83-90.

Lavaleye, M., Duineveld, G., Lundälv, T., White, M., Guinan, D., Kiriakoulakis, K. Wolff, G.A., 2009. Cold-water corals on the Tisler Reef. Preliminary observations on the dynamic reef environment. Oceanography 22, 76-84.

Lazar, K.E., Frazer, T.K., Jacoby St, C.A., Mary, C.M., 2011. Reproductive strategy of Siderastrea radians in the St. Martins Keys, Florida. Bulletin of Marine Science 87, 91-111.

Lessard-Pilon, S.A., Podowski, E.L., Cordes, E.E., Fisher, C.R., 2010. Megafauna community composition associated with Lophelia pertusa colonies in the Gulf of Mexico. Deep Sea Research Part II: Topical Studies in Oceanography 57, $1882-1890$.

Leverette, T.L., Metaxas, A., 2005. Predicting habitat for two species of deep-water coral on the Canadian Atlantic continental shelf and slope. In: Freiwald, A. Roberts, J.M. (Eds.), Cold-Water Corals and Ecosystems. Springer, Berlin, pp. 467-479.

Lidgren, G., Bohlin, L., 1988. Studies of Swedish marine organisms, part X. Biologically active compounds from the marine sponge Geodia Baretti. Journal of Natural Products 51, 1277-1280.

López Correa, M., Freiwald, A., Hall-Spencer, J., Taviani, M., 2005. Distribution and habitats of Acesta excavata (Bivalvia: Limidae) with new data on its shell ultrastructure. In: Freiwald, A., Roberts, J.M. (Eds.), Cold-Water Corals and Ecosystems. Springer, Berlin, pp. 173-205.

Mastrototaro, F., D’Onghia, G., Corriero, G., Matarrese, A., Maiorano, P., Panetta, P. Gherardi, M., Longo, C., Rosso, A., Sciuto, F., Sanfilippo, R., Gravili, C., Boero, F., Taviani, M., Tursi, A., 2010. Biodiversity of the white coral bank off Cape Santa Maria di Leuca (Mediterranean Sea): an update. Deep Sea Research Part II: Topical Studies in Oceanography 57, 412-430.

Metaxas, A., Davis, J., 2005. Megafauna associated with assemblages of deep-wate gorgonian corals in Northeast Channel, off Nova Scotia, Canada. Journal of the Marine Biological Association of the UK 85, 1381-1390.

Mienis, F., de Stigter, H.C., de Haas, H., van Weering, T.C.E., 2009. Near-bed particle deposition and resuspension in a cold-water coral mound area at the Southwest Rockall Trough margin, NE Atlantic. Deep Sea Research Part I: Oceanographic Research Papers 56, 1026-1038.

Mikkelsen, N., Erlenkeuser, H., Killingley, J.S., Berger, W.H., 1982 Norwegian corals: radiocarbon and stable isotopes in Lophelia pertusa. Boreas 11, 163-171.

Morisita, M., 1959. Measuring of iterspecific association and similarity between communities. Memoirs of the Faculty of Science Kyushu University Seriesn E Biology 3, 65-80.

Mortensen, P.B., 2001. Aquarium observations on the deep-sea coral Lophelia pertusa (L., 1758) (Scleractinia) and selected associated invertebrates. Ophelia 54, 83-104.

Mortensen, P.B., Buhl-Mortensen, L., 2005. Morphology and growth of the deepwater gorgonians Primnoa resedaeformis and Paragorgia arborea. Marine Biology 147, 775-788.

Mortensen, P.B., Hovland, M., Brattegard, T., Farestveit, R., 1995. Deep water biotherms of scleractinian coral Lophelia pertusa (L.) at $64^{\circ} \mathrm{N}$ on the Norwegian Shelf: Structure and associated megafauna. Sarsia 80, 145-158.

Mortensen, P.B., Buhl-Mortensen, L., Gordon, D.C., 2005. Effects of fisheries on deepwater gorgonian corals in the Northeast Channel, Nova Scotia. In: Barnes, P.W., Thomas, J.P. (Eds.), Benthic Habitats and the Effects of Fishing, 41 American Fisheries Society Symposium, pp. 369-382.

Mortensen, P.B., Buhl-Mortensen, L., Gebruk, A.V., Krylova, E.M., 2008. Occurrence of deep-water corals on the Mid-Atlantic Ridge based on MAR-ECO data. Deep Sea Research Part II: Topical Studies in Oceanography 55, 142-152.

Murillo, F.J., Duran Munoz, P., Altuna, A., Serrano, A., 2011. Distribution of deepwater corals of the Flemish Cap, Flemish Pass, and the Grand Banks of Newfoundland (northwest Atlantic Ocean): interaction with fishing activities. ICES Journal of Marine Science 68, 319-332.

O'Hara, T., Rowden, A.A. Williams, A., 2008. Cold-water coral habitats on seamounts: do they have a specialist fauna? Diversity and Distributions 14 , 925-934.

Orejas, C., Gori, A., Gili, J.M., 2008. Growth rates of live Lophelia pertusa and Madrepora oculata from the Mediterranean Sea maintained in aquaria. Coral Reefs. 27, 255.

Orejas, C., Gori, A., Lo lacono, C., Puig, P., Gili, J.M., Dale, M.R.T., 2009. Cold-wate corals in the Cap de Creus canyon, northwestern Mediterranean: spatial distribution, density and anthropogenic impact. Marine Ecology Progress Series 397, 37-51.

Orejas, C., Ferrier-Pagès, C., Reynaud, S., Gori, A., Beraud, E., Tsounis, G., Allemand, D., Gili, J.M., 2011. Long-term growth rates of four Mediterranean cold-water coral species maintained in aquaria. Marine Ecology Progress Series 429, $57-65$ 
Pile, A.J., Patterson, M.R., Witman, J.D., 1996. In situ grazing on plankton $<10 \mu \mathrm{m}$ by the boreal sponge Mycale lingua. Marine Ecology Progress Series 141, 95-102.

Purser, A., Bergmann, M., Lundälv, T., Ontrup, J., Nattkemper, T., 2009. Use of machine-learning algorithms for the automated detection of cold-water coral habitats: a pilot study. Marine Ecology Progress Series 397, 241-251.

Raes, M., Vanreusel, A., 2006. Microhabitat type determines the composition of nematode communities associated with sediment-clogged cold-water coral framework in the Porcupine Seabight (NE Atlantic). Deep Sea Research Part I: Oceanographic Research Papers 53, 1880-1894.

Reed, J.K., Gore, R.H., Scotto, L.E., Wilson, K.A., 1982. Trophic relationships of decapods associated with shallow- and deep-water Oculina varicose coral reefs. Bulletin of Marine Science 32, 761-786.

Reitner, J., 2005. Calcifying extracellular mucus substances (EMS) of Madrepora oculata-a first geobiological approach. In: Freiwald, A., Roberts, J.M. (Eds.), Cold-Water Corals and Ecosystems. Springer, Berlin, pp. 731-744.

Reveillaud, J., Freiwald, A., Van Rooij, D., Le Guilloux, E., Altuna, A., Foubert, A. Vanreusel, A., Olu-Le Roy, K., Henriet, J.P., 2008. The distribution of scleractinian corals in the Bay of Biscay, NE Atlantic. Facies 54, 317-331.

Risk, M.J., Heikoop, J.M., Snow, M.G., Beukens, R., 2002. Lifespans and growth patterns of two deep-sea corals: Primnoa resedaeformis and Desmophyllum cristagalli. Hydrobiologica 471, 125-131.

Roberts, J.M., 2005. Reef-aggregating behaviour by symbiotic eunicid polychaetes from cold-water corals: do worms assemble reefs? Journal of the Marine Biological Association of the UK 85, 813-819.

Roberts, J.M., Wheeler, A.J., Freiwald, A., 2006. Reefs of the deep: the biology and geology of cold-water coral ecosystems. Science 312, 543-547.

Roberts, J.M., Wheeler, A., Freiwald, A., Cairns, S., 2009. Cold-Water Corals. The Biology and Geology of Deep-Sea Coral Habitats. Cambridge, UK.

Rogers, A.D., 1999. The biology of Lophelia pertusa (Linnaeus 1758) and other deepwater reef-forming corals and impacts from human activities. International Review of Hydrobiology 84, 315-406.

Rosenberg, M.S., Anderson, C.D., 2011. PASSAGE: pattern analysis, spatial statistics, and geographic exegesis, Version 2. Methods in Ecology and Evolution 2, 229-232.

Rossi, S., Tsounis, G., Orejas, C., Padrón, T., Gili, J.M., Bramanti, L., Teixidó, N., Gutt, J., 2008. Survey of deep-dwelling red coral (Corallium rubrum) populations at Cap de Creus (NW Mediterranean). Marine Biology 154, 533-545.

Rowden, A.A., Schlacher, T.A., Williams, A., Clark, M.R., Stewart, R., Althaus, F., Bowden, D.A., Consalvey, M., Robinson, W., Dowdney, J., 2010. A test of the seamount oasis hypothesis: seamounts support higher epibenthic megafauna biomass than adjacent slopes. Marine Ecology an Evolutionary Perspective 31, 95-106.

Rüggeberg, A., Flögel, S., Dullo, W.C., Hissmann, K., Freiwald, A., 2011. Water mass characteristics and sill dynamics in a subpolar cold-water coral reef setting at Stjernsund, northern Norway. Marine Geology 282, 5-12.

Schmiing, M., Afonso, P., Tempera, F., Santos, R., 2009 Integrating Recent and Future Marine Technology in the Design of Marine Protected Areas - the Azores as Case Study. In: Oceans 2009 - Europe, vols 1 and 2. Ieee, New York.

Sherwood, O.A., Edinger, E.N., 2009. Ages and growth rates of some deep-sea gorgonian and antipatharian corals of Newfoundland and Labrador. Canadian Journal of Fisheries and Aquatic Sciences 66, 142-152.

Sherwood, O.A., Heikoop, J.M., Sincliar, D.J., Scott, D.B., Risk, M.J., Shearer, C., Azetsu-Scott, K., 2005. Skeletal Mg/Ca in Primnoa resedaeformis: relationship to temperature?. In: Freiwald, A., Roberts, J.M. (Eds.), Cold-Water Corals and Ecosystems, Springer, Berlin, pp. 173-205.

Sjögren, M., Göransson, U., Johnson, A.L., Dahlström, M., Andersson, R., Bergman, J., Jonsson, P.R., Bohlin, L., 2004. Antifouling activity pf brominated cyclopeptides from the marine sponge Geodia baretti. Journal of Natural Products 67 $368-372$.
Söffker, M., Sloman, K.A., Hall-Spencer, J.M., 2011. In situ observations of fish associated with coral reefs off Ireland. Deep Sea Research Part I: Oceanographic Research Papers 58, 818-825.

Taviani, M., Freiwald, A., Zibrowius, H., 2005. Deep coral growth in the Mediterranean Sea: an overview. In: Freiwald, A., Roberts, J.M. (Eds.), Cold-Water Corals and Ecosystems. Springer, Berlin, pp. 137-156.

Thiem, Ø., Ravagnan, E., Fosså, J.H., Berntsen, J., 2006. Food supply mechanisms for cold-water corals along a continental shelf edge. Journal of Marine Systems 60, 207-219.

Thorsnes, T., Fosså, J.H., Christensen, O., 2004. Deep-water coral reefs. Acoustic recognition and geological setting. Hydro. International 8, 26-29.

Thomsen, L., 1998. Processes in the benthic boundary layer at continental margins and their implication for the benthic carbon cycle. Journal of Sea Research 41 , 73-86.

Tong, R., Purser, A., Unnithan, V., Guinan, J., 2012. Multivariate statistical analysis of dirstribution of deep-water gorgonian corals in relation to seabed topography on the Norwegian Margin. PLoS ONE 7 (8), e43534, http://dx.doi.org/ 10.1371/journal.pone.0043534.

Tracey, D.M., Rowden, A.A., Mackay, K.A., Compton, T., 2011. Habitat-forming coldwater corals show affinity for seamounts in the New Zealand region. Marine Ecology Progress Series 430, 1-22.

Van Oevelen, D., Duineveld, D., Lavaleye, M., Mienis, F., Soetaert, K., Heip, C.H.R., 2009. The cold-water coral community as a hotspot for carbon cycling on continental margins: a food-web analysis from Rockall Bank (northeast Atlantic). Limnology and Oceanography 54, 1829-1844.

Vertino, A., Savini, A., Rosso, A., Di Geronimo, I., Mastrototaro, F., Sanfilippo, R., Gay, G., Etiope, G., 2010. Benthic habitat characterization and distribution from two representative sites of the deep-water SML coral province (Mediterranean). Deep Sea Research Part II: Topical Studies in Oceanography 57, 380-396.

Wagner, H., Purser, A., Thomsen, L., Jesus, C.C., Lundälv, T., 2011. Particulate matter fluxes and hydrodynamics at the Tisler cold-water coral reef. Journal of Marine Science 85, 19-29.

Wainwright, S.A., Dillon, J.R., 1969. On the orientation of sea fans (genus Gorgonia). The Biological Bulletin 136, 130-139.

Warner, G.F., 1977. On the shapes of passive suspension feeders. In: Keegan, B.F., Ceidigh, P.J.S., Boaden, P.J.S. (Eds.), Biology of Benthic Organisms. Pergamon, Oxford, pp. 567-576.

Watanabe, S., Metaxas, A., Sameoto, J., Lawton, P., 2009. Patterns in abundance and size of two deep-water gorgonian octocorals, in relation to depth and substrate features off Nova Scotia.). Deep Sea Research Part I: Oceanographic Research Papers 56, 2235-2248.

Wehrmann, L.M., Knab, N.J., Pirlet, H., Unnithan, V., Wild, C., Ferdelman, T.G., 2009. Carbon mineralization and carbonate preservation in modern cold-water coral reef sediments on the Norwegian shelf. Biogeosciences 6, 663-680.

Wheeler, A.J., Beyer, A., Freiwald, A., 2007. Morphology and environment of deepwater coral mounds on the NW European margin. International Journal of Earth Sciences 96, 37-56.

Wild, C., Mayr, C., Wehrmann, L., Schöttner, S., Naumann, M., Hoffmann, F., Rapp, H.T., 2008. Organic matter release by cold water corals and its implication for fauna-microbe interaction. Marine Ecology Progress Series 372, 67-75.

Wilson, J.B., 1979. The distribution of the coral Lophelia pertusa (L.) (L. prolifera (Pallas)) in the north-east Atlantic. Journal of the Marine Biological Association of the UK 59, 149-164.

White, M. 2007. Benthic dynamics at the carbonate mound regions of the Porcupine Sea Bight continental margin. International Journal of Earth Sciences 96, 1-9.

Zibrowius, H., 1984. Taxonomy in ahermatypic scleractinian corals. Palaeontographica Americana 54, 80-85. 